\title{
A New System of Corporate Governance: The Quinquennial Election of Directors
}

\author{
Martin Lipton and Steven A. Rosenblum $\dagger$
}

\section{INTRODUCTION}

Corporate governance is a means, not an end. Before we can speak intelligently about corporate governance, we must define its goals. In much of the recent academic literature on corporate governance, however, the goals are either ill-defined or assumed without examination. Academic writers commonly assume that a corporate governance system should be designed primarily to ensure that the actions of a corporation's managers and directors accurately reflect the wishes of its stockholders. ${ }^{1}$ This assumption rests in turn on the premise that stockholders, as owners of the corporation, have the intrinsic right to dictate the corporation's course and receive its profits. Once this premise is accepted, the recognition of the separation of ownership and management as the central characteristic of the modern public corporation ${ }^{2}$ leads inexorably to the conclusion that the central goal of corporate governance is to discipline managers, that is, make managers conform their actions to the desires of stockholders.

This line of academic analysis has coincided with the rise of hostile takeovers. Ignoring the quite varied sources and motivations of hostile acquirors, academic writers have embraced the hostile takeover as the free-market device to rid corporations of bad managers and give stockholders their entitled profit in the pro-

\footnotetext{
† Members of the Firm of Wachtell, Lipton, Rosen \& Katz, New York. The authors' colleague, Yvonne M. Dutton, assisted in the preparation of this Article.

${ }^{1}$ See, for example, Frank H. Easterbrook and Daniel R. Fischel, The Proper Role of a Target's Management in Responding to a Tender Offer, 94 Harv L Rev 1161, 1191, 1201 (1981) (managerial passivity in response to takeovers best serves stockholder interests); Ronald J. Gilson and Reinier Kraakman, Reinventing the Outside Director: An Agenda For Institutional Investors 31-32, 38, 46-48 (John M. Olin Program in Law and Economics, Stanford University Law School, 1990) (on file with U Chi L Rev) (proposing a corps of professional outside directors dependent on institutional stockholders, not management, for their positions); Louis Lowenstein, What's Wrong with Wall Street: Short-term Gain and the Absentee Shareholder 209-18 (Addison-Wesley, 1988) (institutional stockholders should nominate 20-25 percent of board, to encourage their participation in corporate governance).

${ }^{2}$ See generally Adolf A. Berle and Gardiner C. Means, The Modern Corporation and Private Property (Harcourt, Brace \& World, rev ed 1968).
} 
cess. $^{3}$ Accordingly, these writers have proposed corporate governance rules designed to ensure that corporate managers and directors cannot impede a hostile takeover.

Upon examination, however, the unspoken premises of this body of academic literature are seriously flawed. First, there is no basis for the assumption of intrinsic rights and entitlements in the corporate structure. The Anglo-American corporate form is a creation of the state, conceived originally as a privilege to be conferred on specified entities for the public good and welfare. While the corporate form became more widely available as the economy demanded it, and is now generally available to any business, it remains a legal creation. As with any legal construct, we must justify the rules governing it on the basis of economic and social utility, not intrinsic rights. If alteration of those rules benefits the economic system and, in the long run, the corporations themselves, notions of "intrinsic rights" should not stand in the way.

Second, the academic literature has vastly overstated the benefits of the hostile takeover. Even if one accepts the priority of disciplining managers, the hostile takeover has proven a particularly destructive and inefficient means of such discipline. Hostile takeovers have not led managers to manage more effectively or to create more successful business enterprises. Instead, together with the increasing dominance of institutional stockholders, hostile takeover activity has led to an inordinate focus on short-term results and a dangerous overleveraging of the American and British economies, the ill effects of which are only beginning to emerge.

The present lull in hostile takeover activity provides an opportunity to reexamine our system of corporate governance relatively free of the high emotions of the 1980s. But the need for reexamination remains pressing. While the pace of hostile takeover activity has slowed, reflecting in part the current recession, hostile takeovers remain very much a part of the corporate landscape and managerial thinking. Moreover, the growing power of institutional stockholders, and their increasing willingness to exercise that

\footnotetext{
${ }^{3}$ See, for example, Easterbrook and Fischel, $94 \mathrm{Harv}$ L Rev at 1198 (cited in note 1) (managerial passivity in response to tender offers forces managers to put stockholder wealth ahead of their desires to protect their own positions); Lucian A. Bebchuk, The Case For Facilitating Competing Tender Offers, 95 Harv L Rev 1028 (1982) (supporting a rule of auctioneering, rather than passivity, in which incumbent management solicits competing bids); Ronald J. Gilson, A Structural Approach to Corporations: The Case Against Defensive Tactics in Tender Offers, 33 Stan L Rev 819, 878-79 (1981) (proposing a rule that limits management's ability to interfere with stockholders' decision to accept or reject tender offers).
} 
power, create pressures on corporate managers as great as those imposed by the last takeover wave. With the early corporate governance agenda of institutional stockholders focusing on opposition to takeover defenses and promotion of short-term profits, it is imperative that we reach a collective judgment as to the appropriate goals of corporate governance and the best means of meeting those goals.

This Article rejects the approach, which we will refer to as the "managerial discipline model," that assumes that conformity to stockholder wishes and protection of hostile takeovers are the primary goals of corporate governance. Instead, this Article argues that the ultimate goal of corporate governance is the creation of a healthy economy through the development of business operations that operate for the long term and compete successfully in the world economy. Corporate governance is a means of ordering the relationships and interests of the corporation's constituents: stockholders, management, employees, customers, suppliers, other stakeholders and the public. The legal rules that constitute a corporate governance system provide the framework for this ordering. This Article argues that the legal rules, the system of corporate governance, should encourage the ordering of these relationships and interests around the long-term operating success of the corporation. For it is this goal that will ultimately be the most beneficial to the greatest number of corporate constituents, including stockholders, and to our economy and society as a whole.

The system of corporate governance we propose places particular emphasis on the need for cooperation between managers and their principal institutional stockholders. The relationship between managers and stockholders is a problematic one in the modern public corporation, one that is dominated alternately by apathy and confrontation. The academic focus on the discipline of managers threatens to exacerbate the confrontational side of the relationship. What is needed is a system that will lead managers and stockholders to work cooperatively towards the corporation's longterm business success.

Part I of this Article examines the premises and flaws of the managerial discipline model of corporate governance. Part II examines the interest of the corporation in its long-term success as a business enterprise, and the harm to corporate and national interests inflicted by the short-termism that has resulted from changes in the nature of stock ownership and the rise in hostile takeover activity. Part III considers alternative approaches to corporate governance exemplified by the Japanese and German systems, and 
suggests some of the practical constraints in implementing these approaches in the United States and United Kingdom economies. Part IV proposes a new corporate governance system for the United States and the United Kingdom, designed to balance the need for a long-term orientation with the need for managerial accountability. This proposal would replace annual elections of directors with quinquennial elections; bar nonconsensual changes in control between elections; provide major stockholders with direct access to the corporate proxy machinery in connection with the quinquennial election; provide for a detailed five-year report, which would be independently evaluated by an outside advisor, analyzing the corporation's prior five-year performance and setting forth its prospective five-year plan; and tie significant management compensation awards, as well as significant penalties, to the corporation's performance against the five-year plan.

\section{The Managerial Discipline Model}

The academic community has generally embraced the managerial discipline model of corporate governance, which seeks to conform managerial behavior to the wishes of the corporation's stockholders and to prevent managers and directors from impeding hostile takeovers. ${ }^{4}$ Judicial norms, for the most part, have also followed the view of the supremacy of the stockholder in the corporate structure. ${ }^{5}$ Within the last few years, statutory and case law, largely at the urging of non-academic commentators, has begun to give legal recognition to the importance of long-term planning and non-stockholder constituencies in the health of corporations and the corporate economy. ${ }^{6}$ This recognition, however, has been spo-

- For examples of the academic view, see sources cited in notes 1 and 3 .

- For examples of the judicial view, see Dynamics Corp. of America v CTS Corp., 794 F2d 250, 256 (7th Cir 1986) (primary criterion for judging legality of poison pill is "the goal of stockholder wealth maximization"), rev'd on other grounds, 481 US 69 (1987); Revlon Inc. $v$ MacAndrews \& Forbes Holdings, Inc., 506 A2d 173, 182, $184 \mathrm{n} 16$ (Del 1986) (after deciding to sell company, directors may only consider interests of the stockholders); Dodge $v$ Ford Motor Co., 204 Mich 459, 170 NW 668, 684 (1919) ("A business corporation is organized and carried on primarily for the profit of the stockholders.").

- For examples of commentators' views, see Martin Lipton, Corporate Governance in the Age of Finance Corporatism, $136 \mathrm{U}$ Pa L Rev 1, 35-43 (1987); William H. Steinbrink, Management's Response to the Takeover Attempt, 28 Case W Res L Rev 882 (1978); Nicholas F. Brady, Secretary of the Treasury, Remarks before the Business Council (Feb 22, 1990) (on file with U Chi L Rev). For examples of judicial decisions, see Paramount Communications, Inc. $v$ Time Inc., 571 A2d 1140, 1153 (Del 1989) (In evaluating a takeover bid, directors need not maximize short-term stock price and may consider " the impact on "constituencies" other than shareholders .... ,") (quoting Unocal Corp. v Mesa Petroleum Co., 493 A2d 946, 955 (Del 1985)); TW Services, Inc. v SWT Acquisition Corp., [1989 
radic and non-systematic, and has engendered much criticism from academic circles. ${ }^{7}$

In this Part, we analyze three intellectual underpinnings of the managerial discipline model: the paradigm of the stockholder as property owner; the notion that managers are self-interested and require external discipline in order to run their companies well; and the view that the hostile takeover is an effective instrument of discipline. We conclude that each of these concepts is deeply flawed, and that the managerial discipline model is thus inadequate as the basis for a system of corporate governance.

\section{A. The Stockholder as Property Owner}

The managerial discipline model of corporate governance rests in large part on the paradigm of the stockholder as owner of the corporation, standing in much the same relationship to the corporation as the owner of any item of private property stands to that property..$^{8}$ One of the fundamental principles of a capitalist legal system is that the owner of private property may do with that property as he wishes, so long as he does not harm third parties. Once one accepts the premise that stockholders own the corporation in the same manner as they own any other private property,

Transfer Binder] Fed Secur L Rptr (CCH) I 94,334 at 92,173 (Del Chanc 1989) (directors need not pursue immediate maximization of share value by redeeming rights plan at expense of long-term business plan).

Chancellor William T. Allen of the Delaware Chancery Court noted in a recent speech, "The assumption that we want corporation law to more perfectly align manager action with shareholder interest is fundamental to the traditional legal view of the domain of corporation law. But that assumption was tested in the takeover setting in the 1980s and guess what? As George Gershwin put it, it ain't necessarily so." William T. Allen, Competing Conceptions of the Corporation in American Law 9 (Rocco J. Tresolini Lecture in Law, Lehigh University, Oct 29, 1990) (on file with U Chi L Rev). Because about 50 percent of the major public companies are incorporated in Delaware, the Delaware courts, more than any others, have been compelled to be the judicial arbiters of the corporate governance debate. Chancellor Allen, in his decisions and speeches, has demonstrated a keen understanding of corporate governance issues and the ramifications of judicial decisions on the business and policies of corporations. Together with the Delaware Supreme Court, he has fashioned a series of decisions, including the Time and TW Services cases cited above, that have enabled boards of directors to blunt, if not defeat, some of the ill effects of the takeover wave of the 1980s.

${ }^{7}$ See, for example, Easterbrook and Fischel, 94 Harv L Rev at 1190-92 (cited in note 1) (criticizing the view of some commentators that, in responding to a tender offer, the target board should consider the interests of various non-investor groups); Gilson, 33 Stan L Rev at 862-65 (cited in note 3) (rejecting the argument that responsiveness to non-stockholder constituencies justifies management discretion in preventing tender offers).

- See, for example, Frank H. Easterbrook and Daniel R. Fischel, Takeover Bids, Defensive Tactics, and Shareholders' Welfare, 36 Bus Law 1733, 1733 (1981) ("corporations exist and conduct their affairs for the benefit of the shareholders"). 
the conclusion that the wishes of the stockholders must be the paramount focus of the corporation follows, constrained only by the limitation on injuring third parties embodied in concepts such as environmental or products liability tort principles. From this starting point, the descriptive observation that separation of ownership and management is the central characteristic of the modern public corporation leads to the normative conclusion that the primary goal of corporate governance is to ensure that managerial actions conform to the wishes of stockholders. If the corporation is simply private property for the stockholders to do with as they please, the directors and managers of the corporation should, ideally, be no more than implementers of the stockholders' desires.

This line of reasoning, however, suffers from two major flaws. First, the corporation, particularly the modern public corporation, is not private property like any other private property. ${ }^{9}$ Rather, it is the central productive element of the economies of the United States and the United Kingdom. The health and stability of these economies depends on the ability of corporations to maintain healthy and stable business operations over the long term and to compete in world markets. ${ }^{10}$ The corporation affects the destinies of employees, communities, suppliers, and customers. All these constituencies contribute to, and have a stake in, the operation, success, and direction of the corporation. Moreover, the nation and the economy as a whole have a direct interest in ensuring an environment that will allow the private corporation to maintain its long-term health and stability. Rules of corporate ownership and governance must take account of many more interests than do the rules governing less complex property.

The origins of the public corporation reinforce this contrast with ordinary private property. Corporations came into being in England and the United States as quasi-public entities, granted legislative charters to serve specific public as well as private purposes. ${ }^{11}$ Companies such as the British East India Company and

- Professor Berle divides property into two classifications: (1) consumption property and (2) productive property-"property devoted to production, manufacture, service or commerce, and designed to offer, for a price, goods or services to the public from which a holder expects to derive a return." Berle and Means, The Modern Corporation at xi (cited in note 2).

${ }^{10}$ Capitalism, The Economist 5, 6 (May 5, 1990) ("Capitalism") ("The proper 'micro' in microeconomics is the individual firm. How well it does, multiplied by thousands and millions of times, determines how well the economy does.").

12 Berle and Means, The Modern Corporation at 120 (cited in note 2). For an overview of the corporation in American law, see generally Lawrence M. Friedman, A History of American Law 511-25 (Simon \& Schuster, 2d ed 1985). 
the Hudson Bay Company were political instrumentalities as well as profit-making enterprises. ${ }^{12}$ Legislatures granted charters to early American corporations so that religious, educational, and charitable organizations could hold property and act as independent legal entities. Later charters established banks, canal companies, aqueduct companies, and other businesses essential for trade and city development. ${ }^{13}$ General incorporation statutes did not become predominant until the late nineteenth century. ${ }^{14}$ This authorization of general incorporation rights reflected a policy choice to encourage the general aggregation of capital by freeing the owner/stockholders from the risk of unlimited liability.

Given the corporation's origins as a historical and legal construct created for specific public policy reasons, the state naturally may choose to condition the use of the corporate form upon compliance with rules that advance societal goals, even if those goals clash with stockholder interests. For example, corporations must observe laws governing polluting, worker safety, child labor, the right of workers to unionize, foreign corrupt practices, product safety, and a host of other corporate behavior that affects society at large. There is no a priori reason why rules of corporate governance should not similarly take account of public purposes. To the extent there is an intrinsic nature to the corporation, it is more akin to that of a citizen, with responsibilities as well as rights, than to that of a piece of private property.

Second, the managerial discipline model tends to ignore or dismiss the implications for corporate governance of the changing nature of corporate ownership. Just as the corporation is not analogous to ordinary private property, neither is the stockholder in the modern public corporation analogous to the owner of ordinary private property. The stockholder owns an interest in a share of stock, a financial investment granting no direct control over the properties, equipment, contract rights, organizational structure, and other elements that make up the corporation itself. That share may entitle the stockholder to a percentage of the profits and

12 Samuel Williston, History of the Law of Business Corporations Before 1800, 2 Harv L Rev 105, 108-11 (1888).

${ }^{13}$ James Willard Hurst, The Legitimacy of the Business Corporation in the Law of the United States 1780-1970 13-20 (Virginia, 1970); Ronald E. Seavoy, The Origins of the American Business Corporation, (1784-1855) 5-7 (Greenwood, 1982). See also Liggett Co. $v$ Lee, 288 US 517, 545 (1933) (Brandeis dissenting) (early charters granted only when necessary to procure some specific community benefit).

${ }^{14}$ See Berle and Means, The Modern Corporation at 126-27 (cited in note 2) (discussing the appearance of the early general incorporation statutes). 
residual value of the corporation, but the stockholder's intrinsic ownership interest is a financial interest, on which there is a return in the form of dividends or appreciation in trading price, rather than the "use and enjoyment" interest of the owner of a piece of personal property.

Moreover, unlike the stockholder/manager of the nineteenth century corporation or the modern incorporated proprietorship, the stockholder of the modern public corporation does not behave as a traditional owner of property. The stockholder/managers of a closely held corporation have an interest in developing the corporation, nurturing its business, preserving its strength, and ensuring its future. Their shares are not publicly traded and are usually not traded at all. In contrast, the stockholder/investors of the modern publicly held corporation view the corporation more as the holder of a betting slip views a racehorse. ${ }^{16}$ Just as the bettor does not really care about the fate of the racehorse as long as it provides him a financial payoff, so too the stockholder/investor does not really care about the fate of the corporation as long as the stock generates a profit.

The paradigm of the stockholder as the owner of private property, then, does not provide a compelling basis for the managerial discipline model of corporate governance. The economic and political justifications for our-legal rules of private property do not transfer automatically to the rules governing the relationship between stockholder and corporation. ${ }^{16}$ It is simply not a sufficient or compelling answer to the question of why the desires of stockholders must be the paramount and controlling focus of the corporation to say that the stockholders are the owners of the corporation. Of course, stockholders deserve a prominent voice in corporate governance. ${ }^{17}$ Indeed, the proposal for a revised corporate governance system advanced in Part IV looks to stockholders to provide real and ultimate control over the corporation's direction. But the ordering of relationships among corporate constituents that is corporate governance cannot blindly follow the maxim that stockholders own the corporation and must be free to do with it as they please.

18 Capitalism at 8 (cited in note 10 ).

18 As Chancellor Allen states, "The premise of 'ownership' simply assumes but does not justify an answer." Allen, Competing Conceptions of the Corporation in American Law at 15 (cited in note 6).

17 Professors Gilson and Kraakman assert that "managerialist rhetoric" views the institutional investor as less than a real stockholder, and one whose interests "may be appropriately ignored." Gilson and Kraakman, Reinventing the Outside Director at 1 (cited in note 1). This argument is a straw man. 
Rather, we must examine, justify, and if necessary modify our corporate governance system in terms of its impact on stockholders, the corporation and its other constituents, and the health of our economic system and society as a whole.

\section{B. The Need for External Discipline}

The managerial discipline model assumes that managers are inherently self-interested and that, left to their own devices, they will act selfishly and to the detriment of the corporation and its other constituencies, particularly the stockholders. ${ }^{18}$ This bias, however, is simply unfounded. In our experience, most managers and directors act diligently and in good faith to develop and maintain the business success of the corporations they manage or direct. ${ }^{19}$ Only the rare manager or director steals, whether literally or figuratively, from the corporation for personal gain. Certainly, the problem does not warrant the obsession of many academic writers with the issue. Of course, diligence and good faith do not ensure good or successful management. But the kind of discipline contemplated by the managerial discipline model, primarily the threat of takeover or replacement, is directed at the misperceived problem of managerial selfishness, not managerial ability.

Proponents of the managerial discipline model tend to view any action taken by managers that conflicts with the wishes of the stockholders as evidence of managerial self-interest. Thus, they characterize the adoption of antitakeover devices as management entrenchment, ${ }^{20}$ and business acquisitions that hurt short-term earnings as managerial self-aggrandizement. ${ }^{21}$ In so doing, they ignore the possibility that, to the extent these actions conflict with the wishes of stockholders, the divergence may simply reflect dif-

1s See, for example, Easterbrook and Fischel, 94 Harv L Rev at 1169-70 (cited in note 1) (discipline necessary because some managers "will find it advantageous to shirk responsibilities, consume perquisites, or otherwise take more than the corporation promised to give them"); Gilson, 33 Stan L Rev at 836 (cited in note 3) (managers "can be expected, if otherwise unconstrained, to maximize their own welfare rather than the shareholders" ").

10 See also Jay W. Lorsch, Pawns or Potentates: The Reality of America's Corporate Boards 30 (Harvard Business School Press, 1989) ("America's boards are made up of, by and large, responsible and dedicated directors who take their duties seriously.").

20 See, for example, Easterbrook and Fischel, 94 Harv L Rev at 1175 (cited in note 1) (To protect their salaries and status, managers of target company "may disguise a policy of resistance to all offers as a policy of searching for a better offer than any made so far.").

${ }^{21}$ See, for example, Michael C. Jensen and Kevin J. Murphy, CEO Incentives-It's Not How Much You Pay, But How, Harv Bus Rev 36, 45 (May-June 1990) ("Executives are invariably tempted to acquire other companies and expand the diversity of the empire, even though acquisitions often reduce shareholder wealth."). 
fering perspectives as to the appropriate direction and business plan of the corporation. While a stockholder seeking a short-term premium may object to takeover impediments, antitakeover provisions can be a quite rational tool for a board of directors seeking to preserve the corporation in the face of an attempted takeover that is likely to be detrimental to the long-term health of its business. Similarly, while a stockholder with a short-term investment horizon may object to a business combination that initially hurts the corporation's earnings per share, the business combination may reflect the good faith judgment of the corporation's directors and managers that the step is necessary to position the corporation to prosper over the long term.

The managerial discipline model also dismisses the substantial common law and statutory legal strictures already in place that address overt self-dealing or self-interestedness. Transactions with the corporation in which a director or manager has a personal financial interest receive close scrutiny. ${ }^{22}$ Insider trading rules ${ }^{23}$ and short-swing profit recovery ${ }^{24}$ guard against the misuse of information in stock trading by directors and managers. Moreover, substantial existing financial and social incentives motivate directors and managers to seek the business success of the corporations they direct or manage. Incentive compensation based on appreciation of the stock of the corporation, or based on increasing earnings and exceeding budget targets, provides managers with financial rewards

22 See, for example, Fliegler $v$ Lawrence, 361 A2d 218, 221 (Del 1976) (where defendants stood on both sides of transaction, burden was on defendants to demonstrate transaction's intrinsic fairness to the acquiring firm and its stockholders); $A C$ Acquisitions Corp. $v$ Anderson, Clayton and Co., 519 A2d 103, 111 (Del Chanc 1986) (board with financial interest in transaction adverse to corporation bears burden of proving the transaction's intrinsic or objective fairness); Guth $v$ Loft, Inc., 23 Del Chanc 255, 5 A2d 503, 510 (1939) (rule demands of a director the most scrupulous observance of his duty to "refrain from doing anything that would work injury to the corporation, or to deprive it of profit or advantage which his skill and ability might properly bring to it, or to enable it to make in the reasonable and lawful exercise of its powers"). In addition to case law, approximately three-quarters of the states have enacted statutory provisions governing contracts with interested directors. See, for example, 8 Del Code Ann § 144 (1990).

2s Section 10(b) of the Securities Exchange Act of 1934, 15 USC \$ 78j (1988), and Rule 10b-5 promulgated thereunder, require that an insider who possesses material nonpublic information about a company make appropriate disclosure of the information or abstain from trading in the company's stock. See In re Cady, Roberts \& Co., 40 SEC 907, 911 (1961).

24 Section $16(\mathrm{~b})$ of the Securities Exchange Act of 1934,15 USC $\S 78 \mathrm{p}(\mathrm{b})$, provides for a rule of strict liability, entitling an issuer to recover any profits realized by a director, officer, or beneficial owner of ten percent of an issuer's outstanding stock, from the purchase or sale of any equity security of the issuer. 
tied to the success of the corporation. ${ }^{25}$ An executive's social status, and the respect of fellow executives, typically depend in large part on the success of the corporation he or she manages. Independent directors' reputations, and to some extent their opportunities to serve on other boards, are tied to the business success of their corporations. $^{26}$

The managerial discipline model's emphasis on reining in managerial self-interest is thus just as flawed as its emphasis on conforming the actions of managers to the desires of the stockholders. The greater problem, or challenge, is to design a system that gives managers the opportunity and the incentive to work in partnership with stockholders and the corporation's other constituencies in improving the long-term business performance of the corporation. The quinquennial proposal advanced in Part IV addresses this problem.

\section{Hostile Takeovers as an Instrument of Discipline}

Academic proponents of the managerial discipline model of corporate governance tend to embrace the hostile takeover as the primary instrument of managerial discipline. They argue that bad, inefficient, or self-interested managers, or managers who fail to heed the wishes of the stockholders, will find themselves vulnerable to a hostile takeover. If the state does not permit incumbent management to interfere with stockholders' freedom to accept tender offers, the argument continues, the fear of a hostile takeover will make bad managers good, inefficient managers efficient, and self-interested managers responsive to stockholder desires. ${ }^{27}$ In

${ }^{25}$ The quinquennial proposal set forth in Part IV suggests tying these financial incentives to the performance of the corporation over five-year periods as part of the effort to reorient the corporation towards long-term business performance. See Part IV.E.

${ }^{26}$ See Eugene F. Fama, Agency Problems and the Theory of the Firm, $88 \mathrm{~J}$ Pol Econ 288, 294 \& n 3 (1980) (discussing market for outside directors: "Like the professional outside director, the welfare of the outside auditor depends largely on 'reputation.' "). But see Gilson and Kraakman, Reinventing the Outside Director at 22-23 \& nn 41-42 (cited in note 1) (arguing that no effective market for outside directors exists). While perhaps not as developed as the market for outside auditors, our experience is that reputation is important in creating opportunities for outside directors.

${ }^{27}$ See, for example, Gilson \& Kraakman, Reinventing the Outside Director at 12-13 (cited in note 1) (mere threat of hostile offer is likely to improve target management); Easterbrook and Fischel, $94 \mathrm{Harv} L \mathrm{Rev}$ at 1169 (cited in note 1) ("tender bidding process polices managers whether or not a tender offer occurs"); ALI, Principles of Corporate Governance: Analysis and Recommendations part VI at 98 (Tent Draft No 10, 1990) ("[T]ender offers are mechanisms through which market review of the effectiveness of management's delegated discretion can operate."). See also Finnegan v Campeau Corp., 915 F2d 824, 831 (2d Cir 1990) ("Congress realized "that takeover bids should not be discouraged 
practice, however, the hostile takeover is not a particularly effective or efficient means of motivating or disciplining managers.

The enthusiasm for the hostile takeover as the primary instrument of managerial discipline rests heavily on the efficient capital markets theory that has dominated the academic literature over the last two decades. This theory holds, in essence, that the market price of a corporation's stock at any given time accurately reflects all available information about the corporation and its anticipated future income stream. Accordingly, the argument continues, the market can neither undervalue nor overvalue a corporation's worth. ${ }^{28}$ The willingness of an acquiror to pay a premium to the market price, then, necessarily implies that the acquiror can increase the value of the corporation by managing the assets better, thus demonstrating the inefficiency of the existing management.

In recent years, however, the efficient capital markets theory has become increasingly discredited, especially since the stock market crash of October $1987 .{ }^{29}$ A growing body of economic literature now accepts that the stock market can and does misprice particular stocks, groups of stocks, and even stocks in general for extended periods of time. ${ }^{30}$ The new literature recognizes the great degree of subjectivity, and even irrationality, among investors who set the demand for and the price of stocks. ${ }^{31}$ Recent literature also

because they serve a useful purpose in providing a check on entrenched but inefficient management.' ") (quoting legislative history of the Williams Act, S Rep No 90-550, 90th Cong, 1st Sess $3(1967))$.

${ }^{28}$ See, for example, Easterbrook and Fischel, 36 Bus Law at 1734 (cited in note 8) ("[T]he notion that stock is priced in the market at less than its true value is implausible."); Werner F.M. De Bondt and Richard H. Thaler, A Mean-Reverting Walk Down Wall Street, $3 \mathrm{~J}$ Econ Persp 189, 189 (1989) ("Few propositions in economics are held with more fervor than the view that financial markets are 'efficient' and that the prices of securities in such markets are equal to their intrinsic values.").

28 Andrei Shleifer and Lawrence H. Summers, The Noise Trader Approach to Finance, $4 \mathrm{~J}$ Econ Persp 19, 29 (1990) ("[S]tock in the efficient markets hypothesis-at least as it has traditionally been formulated-crashed along with the rest of the market on October 19, 1987," when "a 22 percent devaluation of the American corporate sector" occurred in one day.).

so See Stephen F. LeRoy, Efficient Capital Markets and Martingales, $27 \mathrm{~J}$ Econ Lit 1583, 1616 (1989) ("The most radical revision in efficient-markets reasoning will involve those implications of market efficiency that depend on asset prices equaling or closely approximating fundamental values. The evidence suggests that, contrary to the assertion of this version of efficient markets theory, such large discrepancies between price and fundamental value regularly occur."); E. Victor Morgan and Ann D. Morgan, The Stock Market and Mergers in the United Kingdom 74 (David Hume Institute, 1990) ("There are powerful reasons for believing that equity markets, in the UK and elsewhere, are unlikely to be fundamental-valuation efficient but, in view of the difficulty of testing and the paucity of factual evidence, the question must remain open.").

s1 See, for example, Shleifer and Summers, $4 \mathrm{~J}$ Econ Persp at 19-20 (cited in note 29) 
examines the effects on pricing of varying levels of information among investors, varying investor time horizons, varying evaluations of future prospects and risks, and the greater cost and risk of arbitraging long-term mispricing than short-term mispricing. ${ }^{32}$ Moreover, tax and accounting effects can cause a corporation's stock to be underpriced in the market compared to its worth to an acquiror. ${ }^{33}$ These factors all support the conclusion that the public market may often undervalue the shares of a corporation relative to the worth an acquiror would place on the shares, even in the absence of any efficiency gains from the acquisition.

Professors Shleifer and Summers suggest that another source of takeover activity may be the ability of an acquiror to realize gains from a "breach of trust" with the corporation's other constit-

("Our approach rests on two assumptions. First, some investors are not fully rational and their demand for risky assets is affected by their beliefs or sentiments that are not fully justified by fundamental news. Second, arbitrage-defined as trading by fully rational investors not subject to such sentiment-is risky and therefore limited."); Gavin C. Reid, Efficient Markets and the Rationale of Takeovers 19-23 (David Hume Institute, 1990) (describing "bubbles," in which "prices rise rapidly without apparent good reason, trading volumes accelerate, and prices finally crash," and "fads," in which "social convention or fashion makes certain assets desirable"); De Bondt and Thaler, $3 \mathrm{~J}$ Econ Persp at 199-200 (cited in note 28) (discussing how "faulty risk perceptions," "a tendency to overreact to recent earnings trends," and "biased" immediate price reaction to negative events may result in market undervaluation of a corporation's shares: "For companies that experience a series of "bad events,' the price correction may take several years.").

${ }^{32}$ See Jean A. Crockett, Takeover Attempts, Economic Welfare, and the Role of Outside Directors (Rodney L. White Center for Financial Research, Wharton School of Finance, 1989) (on file with U Chi L Rev) (stock prices can undervalue corporations because of information imperfections and short-term investment horizons); Lynn A. Stout, Are Takeover Premiums Really Premiums? Market Price, Fair Value, and Corporate Law, 99 Yale L $\mathrm{J} 1235,1295$ (1990) (heterogeneous investor valuations create a downward sloping demand curve for a corporation's shares, which implies that takeover premiums "may be natural market phenomena rather than evidence of efficiency gains from acquisitions"); Andrei Shleifer and Robert W. Vishny, The New Theory of the Firm: Equilibrium Short Horizons of Investors and Firms, 80 Am Econ Rev Pap \& Proc 148 (1990) (greater cost of arbitrage in long-term assets compared to short-term assets results in greater mispricing of long-term assets in equilibrium).

ss Tax rules (particularly the tax deductibility of interest payments and non-deductibility of dividend payments) and accounting conventions (particularly the capitalization of acquisition costs in contrast to the current charge for the costs of starting a new business, research and development, and introducing new products) encouraged the acquisitions and leveraging of the last decade and require reexamination, although we do not undertake that task here. See Crockett, Takeover Attempts at 5-6 (cited in note 32) ("When we look at the impact on the economy as a whole, the increment in after-tax earnings for the surviving firm [in a leveraged transaction] must be offset against the loss to the Treasury and ultimately the taxpayers. The effect is primarily an income transfer hard to justify on equity grounds. Furthermore, it is possible that the overall economy will suffer if the higher leverage leads to a higher rate of bankruptcies or serious financial difficulties in the next recession."). 
uents. ${ }^{34}$ They point out that a corporation enters into implicit contracts with constituents such as employees and suppliers. In some circumstances, these implicit contracts may become a liability, but incumbent managers remain committed to upholding them because of the trust relationship between the managers and stakeholders. "In these cases ousting the managers is a prerequisite to realizing the gains from the breach. ... The resulting wealth gains show up as the takeover premia."35 To the extent such breaches of trust account for the takeover premium, the takeover represents a wealth transfer and not an efficiency gain. In this manner, "hostile takeovers can be privately beneficial and take place even when they are not socially desirable."36

A number of other factors also contributed to the hostile takeover explosion of the 1980s. For example, the relative ease of obtaining acquisition financing and leveraged buyout fund capital allowed acquirors to make risky acquisitions with little of their own money invested, and thus little downside risk to themselves. ${ }^{37}$ The ease of obtaining financing also extended to takeover arbitrageurs, who facilitated hostile transactions. ${ }^{38}$ And the arrogance and ego of corporate raiders, seeking to do a bigger or better deal than the one just announced in the financial press, may also have helped fuel the takeover wave. ${ }^{39}$ In sum, it is simply wrong to suggest that

34 Andrei Shleifer and Lawrence H. Summers, Breach of Trust in Hostile Takeovers, in Alan J. Auerbach, ed, Corporate Takeovers: Causes and Consequences 33 (Chicago, 1988). See also J. Mark Ramseyer, Takeovers in Japan: Opportunism, Ideology and Corporate Control, 35 UCLA L Rev 1, 63 (1987) ("A hostile acquisition enables a firm's shareholders to renege on the bargain they initially struck with their managers. In so doing, a hostile acquisition enables the shareholders to appropriate the bulk of any organizational rent the firm earns, even when that rent results from joint investments by shareholders and managers.").

ss Shleifer and Summers, Breach of Trust in Hostile Takeovers, in Auerbach, ed, Cor:porate Takeovers at 41 (cited in note 34 ).

38 Id at 34 .

${ }^{37}$ See, for example, Richard L. Stern and Edward F. Cone, Scarlett O'Hara comes to Wall Street, Forbes 37 (Sept 21, 1987) (investment banks, commercial banks, and insurance companies fight to finance LBOs); Sarah Bartlett, Need A Quick Billion or Two? Just Ask Your Banker, Bus Week 98 (Oct 26, 1987) (big banks providing loans for mergers and LBOs quickly and in huge amounts); Robert L. Messineo, Proposed SEC Rules May Impact LBO Funds, NY L J 5 (Sept 21, 1989) (\$20 billion committed to LBO funds is used to finance sizeable transactions on an expeditious basis).

ss See, for example, Allan Sloan, An Extra Slice of the Pie, Forbes 32 (Feb 9, 1987) (leading takeover arbitrageur Ivan Boesky, together with Drexel Burnham Lambert, raised $\$ 350$ million in equity and $\$ 660$ million in debt for Boesky's takeover arbitrage partnership).

so See Reid, Efficient Markets and the Rationale of Takeovers at 34 (cited in note 31) ("[I]s it not possible that 'noise trading' is also going on, with pathological propensities to 'do a deal' over-riding considerations of net benefit, and thus of efficiency?"). 
bad, inefficient, or self-interested management is the sole or primary source of this takeover activity.

The anecdotal evidence supports this conclusion. In recent years, well-managed corporations have been just as likely as poorly managed corporations to become the target of a hostile takeover. For example, AMR Corporation (the parent of American Airlines) became the subject of a takeover attempt by Donald Trump, although the chairman of AMR is generally recognized as the best manager in the airline industry. ${ }^{40}$ Georgia-Pacific Corporation acquired Great Northern Nekoosa Corporation even though Great Northern Nekoosa's return to stockholders for the prior ten years exceeded that of Georgia-Pacific and the industry as a whole.41 Georgia-Pacific's stock price and earnings have since declined.42 Even noted raider Sir Gordon White, Chairman of Hanson Industries, in defending hostile takeover activity, notes: "There are a large number of companies which are regarded, by and large, as well run. Of course, these companies can be taken over as the result of a hostile bid but the shareholders can and do demand a very high price."43

If poor or inefficient management is not the primary impetus for hostile takeovers, it follows that takeovers do not generally motivate managers to manage better or more efficiently. Rather, the hostile takeover motivates managers to combat the undervaluation of their stock by leveraging the corporation, avoiding investments that do not immediately add to reported earnings, selling assets, or otherwise boosting short-term earnings, regardless of the possible harm to the corporation over the long term. ${ }^{44}$ Even to the extent

to See Judith H. Dobrzynski, Why Even Well-Run Companies Can Be Easy Prey, Bus Week 56 (Oct 23, 1989); Erik Hedegaard, Fasten Your Seatbelt, Bob, It's Going to be a BUMPY Year, M Inc. 61 (Jan 1991) ("American Airlines' Robert Crandall is considered the best in the business.").

42 See Great Northern Nekoosa Corporation Letter to Shareowners (Nov 13, 1989), filed with the Securities and Exchange Commission as Exhibit 15 to Great Northern Nekoosa Corporation Schedule 14D-9 (on file with U Chi L Rev).

42 Jacqueline Bueno, Georgia-Pacific Earnings, Stock Price Take a Tumble, Atlanta Bus Chron 3A (Sept 3, 1990). The authors' law firm represented AMR and Great Northern Nekoosa in these takeover matters. While these two examples do not demonstrate that all takeovers are bad, they do undercut any close linkage between takeovers and incentives for competent management.

's Sir Gordon White, Why Management Must Be Accountable, Financial Times $\$ 1$ at 11 (July 12,1990$)$.

" See, for example, Richard Lambert and Anatole Kalestsky, Jam Today Is What Shareholders Want, Financial Times $\$ 1$ at 21 (July 12, 1989) ("The last-ditch defence against hostile takeovers has thus been for existing managements to steal the raider's thunder by arranging a leveraged buy-out and recapitalisation themselves. . . . Ironically, in many cases it is the existing management, rather than the outside raider, that ultimately 'ads a company up with greater debts and becomes the more ruthless liquidator."); Chris- 
mismanagement does contribute to hostile takeover activity, the threat of a hostile takeover is far more likely to create an attitude of defensiveness on the part of managers than to create an openness to the kind of change and new ideas that might serve to improve business performance. ${ }^{45}$ Some hostile takeovers may replace bad managers with new ones who may or may not be better. But the threat of a hostile takeover is unlikely to improve the performance of bad managers. ${ }^{46}$ Finally, as we discuss in Part II, hostile takeovers and related short-termism have imposed substantial ancillary societal costs.

In sum, the managerial discipline model of corporate governance is not compelling. We must turn, then, to the examination of the corporation's proper place in our economy and society, the challenges for corporate governance, and the question of how best to reconcile the interests of the corporation's various constituents and our economy and society as a whole.

\section{The Interest of the Corporation IN ITS Long-Term Success and the Societal Cost of Short-Termism}

In this Part, we offer an alternative to the managerial discipline model. We argue that the corporation has an independent interest in its own long-term business success. Classical economic theory suggests that this interest, multiplied by many individual

topher Farrell, The Bills Are Coming Due, Bus Week 84 (Sept 11, 1989) (USG Corp. "beat back a takeover raid last year through a $\$ 2.2$ billion recapitalization. . . . USG has slashed its research-and-development staff and expenditures in half, nearly halved capital spending, cut its work force from 21,000 to 16,000 , reduced the management ranks by $10 \%$, and sold assets worth $\$ 600$ million-including highly profitable Masonite Corp. . . Competitors smell blood.").

${ }^{45}$ John C. Coffee, Jr., Regulating the Market for Corporate Control: A Critical Assessment of the Tender Offer's Role in Corporate Governance, 84 Colum L Rev 1145, 1242-43 (1984) (The work of Douglas McGregor and "a legion of other social scientists" suggests that "management will be more effective if it creates an environment that stresses support and encouragement rather than constant threats of dismissal. . . . In this view, the constructive deterrent value of the takeover lies more in its ability to function as the corporate guillotine, amputating swiftly and finally an inefficient management, and less in its general deterrent effect as a motivating force by which marginal managements are spurred to greater effort.").

${ }_{16}$ Melvin Aron Eisenberg, The Structure of Corporation Law, 89 Colum L Rev 1461, 1497-99 (1989) (threat of a takeover may make some managers more efficient, but "the takeover market neither adequately aligns the interests of managers and shareholders, nor adequately addresses the problem of managerial inefficiency"); Coffee, 84 Colum L Rev at 1192 95 (cited in note 45) (capital market is only an effective monitor in cases of massive managerial failure); Michael L. Dertouzos, Richard K. Lester and Robert M. Solow, Made in America: Regaining the Productive Edge 39 (MIT, 1989) ("Only an extraordinary optimist could believe, for example, that the current wave of takeover activity is an efficient way to deal with the organizational deficiencies of American industries."). 
firms, is also society's interest and therefore supplies the proper organizing principle of corporate governance. The ascendancy of the institutional stockholder and the hostile takeover, however, creates an emphasis on short-term results that makes it increasingly difficult for the corporation to maintain the long-term focus necessary to its own and society's well-being. The efficient capital markets theory that underlies academic support for takeovers, and that dismisses the distinction between short-term and long-term interests, has become increasingly discredited. The short-term bias imposed by institutional stockholders and takeover activity is real, and this short-term bias has substantial corporate and societal costs. In this context, the priorities of the managerial discipline model threaten to exacerbate the problems of short-termism. Instead, our rules of corporate governance require the sort of fundamental reform that will align the interests of all corporate constituents toward the long term.

\section{A. The Interest of the Corporation as a Business Enterprise}

At the most basic level, the corporation is no more than a specific legal form of business enterprise. It is a concatenation of factors of production-property, equipment, employees, contract rights, and the like-organized to produce goods and services efficiently. To the extent that the enterprise is able to attract and retain consumers of its products or services who are willing to pay the enterprise more than it costs to produce the products or services, the enterprise will make a profit. The greater the amount of goods or services the enterprise can sell, and the greater the difference between what the consumer is willing to pay and what the goods or services cost to produce, the greater the profit that inures to the enterprise. Viewed in this light, the corporate enterprise has an independent interest of its own in the successful operation of its business, with success measured in terms of present and expected profit. The notion of "the best interest of the corporation" refers to this interest in the present and continuing vitality of the enterprise. ${ }^{47}$

Classical economic theory looks to the profit interest of proprietors to ensure the health of business enterprises and, in turn, of

47 TW Services, Inc, v SWT Acquisition Corp., [1989 Transfer Binder] Fed Sec L Rptr (CCH) I 94,334 at 92,178 (Del Chanc 1989) ("[D]irectors . . . may find it prudent (and are authorized) to make decisions that are expected to promote corporate (and shareholder) long run interests, even if short run share value can be expected to be negatively affected."). 
the national economy. ${ }^{48}$ This theory holds that the profit motive drives each proprietor to produce better goods and services more efficiently than his competitors. As long as private actors have virtually complete freedom to use their resources as they wish, classical economic theory's invisible hand will cause the best and most efficient producers to flourish, direct each factor of production to its best and most efficient use, and lead the economy as a whole to thrive. This is the basis on which the legal and social system justifies granting free rein to the individual's economic self-interest.

This theory, however, originated in a time when most proprietors owned and managed their own enterprises. ${ }^{49}$ Proprietor and enterprise shared identical interests; by making the enterprise more successful and profitable, the proprietor reaped a personal profit. Moreover, the enterprise typically represented the bulk of the proprietor's economic wealth. The proprietor could not simply set it aside and turn to some other investment or pursuit without losing much of his wealth. Accordingly, self-interest dictated that the proprietor seek to develop and maintain the long-term operating success of the enterprise.

The separation of ownership and management dramatically alters this theoretical model. No longer does the profit motive of the corporate owner, with her highly liquid stake and betting-slip mentality, automatically promote the long-term health of the enterprise. Nor does the self-interest and profit motive of the manager, typically insulated from risk by her small ownership stake and by limited liability, automatically create the most efficient and profitable corporation possible.

The managerial discipline model focuses sharply on the potential divergence between managers' interests and the corporation's interest. But, in so doing, it fails to recognize or consider the implications of the potential divergence between stockholders' interests and the corporation's interest. Indeed, most of the academic literature defines the interest of the corporation in terms of the desires of stockholders, thereby assuming away the potential divergence. ${ }^{50}$ As discussed above, however, there is no intrinsic reason that the conformity to the wishes of the stockholders must be the central

48 Adam Smith, The Wealth of Nations Book 4, ch 2 at 419-20 (Methuen, 6th ed 1950) (originally published 1776).

40 Id. See also Berle and Means, The Modern Corporation at 303.08 (cited in note 2).

so See, for example, Easterbrook and Fischel, 36 Bus Law at 1733 (cited in note 8) ("The purpose of corporations law is to establish organizing principles under which shareholders may conduct the enterprise for their own benefit."). 
goal of the corporation. ${ }^{51}$ Rather, the justification for granting free rein to owner or stockholder self-interest, and defining that selfinterest as the interest of the corporation, rests on the classical economic model in which the stockholder/owner/proprietor links her long-term economic well-being to the long-term health of the business enterprise. As and when the underpinnings of this model change, the conclusions and policy decisions generated by the model must be reexamined.

An obvious example of the need to reexamine the model and make periodic adjustments is provided by the development of antitrust laws in the United States and the United Kingdom. These laws, responding to the modern corporation's ability to distort markets through monopolization or anticompetitive pricing, represent an effort to realign the market into conformity with the assumptions of the classical model. Similarly, the separation of ownership and management, and the changing nature of ownership, have undermined the invisible hand model. A corporate governance system based on this model accordingly becomes problematic. Ultimately, the corporate governance system must realign the interests of the corporation's stockholders, managers, and other constituencies to promote the long-term health of the business enterprise. Only then will the pursuit of private interest again serve the public interest as posited by classical economic theory.

\section{B. Short-Termism and the Bias of Institutional Stockholders}

The growing dominance of institutional shareholdings, and the structure within which institutional stockholders now operate, has virtually ensured the divergence of the interests of stockholders and those of the corporation. Institutions now hold more than 45 percent of total equities in the United States, and approximately 52 percent of equity in the 500 largest companies. ${ }^{52}$ The concentration of institutional ownership in the United Kingdom is even greater, exceeding 63 percent. ${ }^{53}$ Institutional stockholders have little incentive or inclination to behave like traditional owners in the classical economic model-that is, to work actively towards the

\footnotetext{
s1 See Part I.A.

62 Carolyn Kay Brancato, The Pivotal Role of Institutional Investors in Capital Markets: A Summary of Economic Research at the Columbia Institutional Investor Project 21 and Table 7 (Center for Law and Economic Studies, Columbia University School of Law, 1990) (on file with U Chi L Rev).

${ }^{8 s}$ See William Taylor, Can Big Owners Make a Difference?, Harv Bus Rev 70 (SeptOct 1990).
} 
long-term operating success of the corporation. They tend to focus instead on the current market price of the corporation's stock. Most institutional stockholders will support a hostile takeover, a sale of assets, a leveraging recapitalization, or any other transaction that boosts the immediate price of the corporation's stock.

The critique of short-term bias is a critique not of the motives or integrity of institutional stockholders, but of the system that has failed to respond to the changing nature of stock ownership. While proposing a corps of professional directors to be nominated and elected by institutional stockholders, Professors Gilson and Kraakman recognize that institutional stockholders currently have little opportunity or incentive to take an interest in the long-term business development of the corporations whose stock they own. ${ }^{54}$ However, they would accept the short-term bias of institutional stockholders and seek to guarantee that the board of directors, in the name of heeding the wishes of stockholders, reflects this bias. In contrast, this Article suggests that the corporate governance system must attempt to counteract this short-term bias and realign the interests of stockholders with the interest of the corporation as an ongoing business enterprise.

Several constraints operate on the institutional stockholder to produce a short-term bias. First, as their stock portfolios have grown in size, institutional stockholders have increasingly lost the ability to assess adequately the business performance of each portfolio company. ${ }^{55}$ For these stockholders, the market price of the corporation's stock has become the only important valuation measure for the corporation, and any step that boosts the short-term price of a portfolio company's stock has become viewed as intrinsically desirable.

Second, institutional stockholders assess the performance of the investment managers who control their stock portfolios over a short time frame, typically quarter to quarter or year to year, on the basis of the change in the portfolio's market value during the specified time period. ${ }^{6}$ The investment manager trying to outperform the market average in each quarter or each year will al-

${ }^{54}$ Gilson \& Kraakman, Reinventing the Outside Director at 6-8 (cited in note 1).

${ }^{85}$ Id at 6-7 (growth of funds under the management of institutional investors whose investment strategy is simply to track the general performance of the market reflects the inability or unwillingness of those stockholders to track the performance of individual corporations); Taylor, Harv Bus Rev at 72 (cited in note 53) ("Of the $\$ 40$ billion in equities owned by the New York funds [three pension funds for retired state and local employees], $\$ 30$ billion are in indexed portfolios.").

${ }^{56}$ See Dertouzos, Lester, and Solow, Made in America at 62 (cited in note 46) (fund 
ways have an incentive to accept, even seek, a short-term premium for a portfolio stock. ${ }^{57}$ This competition among investment managers exacerbates a situation analogous to the "prisoner's dilemma," in which cooperation produces optimal results but rational, selfinterested behavior does not. ${ }^{58}$ Even if the investment manager understands that stockholders as a whole would be better off encouraging and promoting the long-term business development of all corporations, he will still accept, even seek, short-term premiums on his portfolio stocks in an effort to outperform competing investment managers in any given quarter or year.

Finally, the institutional stockholder faces liability constraints. The typical institutional stockholder has a fiduciary duty to the beneficiaries of its portfolio and must act solely in their interest. ${ }^{59}$ While fiduciary status does not intrinsically require a short-term orientation, to the extent the courts and government agencies such as the Department of Labor have accepted the managerial discipline model's short-term bias, the institutional stockholder may fear exposure to liability if it fails to seek or accept the short-term premium for its portfolio shares. ${ }^{60}$

managers rapidly turn over stock holdings since judged on current value of investment portfolio). See also Lipton, $136 \mathrm{U} \mathrm{Pa} \mathrm{L}$ Rev at 7-8 (cited in note 6).

${ }^{87}$ See Crockett, Takeover Attempts at 8 \& $\mathrm{n} 8$ (cited in note 32) (short time horizons of institutional stockholders result from "emphasis ... placed on short-term performance in evaluating and rewarding fund managers").

${ }^{s 8}$ See generally Anatol Rapoport and Albert M. Chammah, Prisoner's Dilemma: A Study in Conflict and Cooperation (Michigan, 15S5).

${ }^{59}$ The Department of Labor (DOL) views the Employee Retirement Income Security Act of 1974 (ERISA), 29 USC $\S \S 1001$ et seq (1988), as requiring plan fiduciaries to consider only the economic interests of the plan participants and beneficiaries in the shares held by the plan when deciding whether to tender shares in a tender offer. While the DOL has stated that plan fiduciaries may weigh the long-term value of the target company in this decision, it also warns that it will monitor plan fiduciaries to ensure that they do not violate ERISA's requirements and are aware of the liability that can result from any such violations. See Press Briefing on ERISA and Takeovers, in 6 Pension \& Profit Sharing (PrenticeHall) I 135,649 at 136,971 (1989). See also David George Ball, Assistant Secretary, Pension \& Welfare Benefits Administration, The Importance of Corporate Governance (speech to United Shareholders' Association, Sept 17, 1990) (on file with U Chi L Rev). In practice, the DOL's statements have resulted in pressure on plan fiduciaries to tender their shares for the immediate premium, in order to avoid liability for incorrectly assessing the long-term value of the target corporation and its prospective return to stockholders.

${ }^{60}$ See, for example, statement of David Walker, Assistant Secretary of Labor, in 6 Pension and Profit Sharing at 136,971 (cited in note 59) (plan fiduciaries must look solely to economic interests of the pension plan, with purpose of maximizing retirement income for beneficiaries); Thomas Gilroy and Brien D. Ward, The Institutional Investor's Duty Under ERISA to Vote Corporate Proxies, in Proxy Contests, Institutional Investor Initiatives, Management Responses 1990 853, 866 (PLI, 1990) (DOL generally claims that ERISA's prudence requirement "obligates the fiduciary to consider only economic factors that affect the value of the plan's investment. For example, the decision to vote for a shareholder initi- 
Commentators outside of academic circles have for some time noted the problem of short-termism. ${ }^{61}$ Because of the influence of the efficient capital markets theory, however, the academic literature has tended to ignore the problem. Under the efficient capital markets theory, the short-term price of a stock reflects the present value of the corporation's long-term results. Adherents of this theory thus define out of existence the distinction between short-term and long-term values or investor orientations. ${ }^{62}$

It is only with the recent undermining of the efficient capital markets theory ${ }^{63}$ that the academic literature, particularly the economic literature, has begun to examine the effects of short-term biases and short-term investment horizons. Professors Shleifer and Vishny, for example, have demonstrated that the short time horizons of arbitrage investors, who focus on short-term assets because they are relatively less expensive to arbitrage, may result in severe market underpricing of a corporation's equity. This phenomenon in turn imposes a short time horizon on managers, who avoid longterm investments that depress share prices over the short term and that thus make the corporation vulnerable to hostile takeover. ${ }^{64}$ They conclude that the "clustering" of arbitrage on the trading of short-term assets "leads to systematically more accurate pricing of short-term assets than of long-term assets, even though efficient capital allocation and managerial evaluation might be better served by the opposite bias."

Other academic writers identify additional sources of shortterm pressures and biases. Stephen LeRoy points to the recent literature on cognitive psychology for the proposition that stockholders "systematically overweight current information and underweight background information,"66 thus producing an artificially

ative in the belief that it will support management's commitment to stimulate job growth in a targeted sector of the economy may, in the DOL's view, violate [the fiduciary duty]."). ERISA provides that a plan fiduciary is "personally liable" for any breach of fiduciary duty. ERISA $\S 409$ (a), 29 USC $\$ 1109$ (a). This provision may be enforced either by a plan participant or beneficiary or by the Department of Labor. ERISA § 502(a)(2), 29 USC § 1132(a)(2).

'S See, for example, John G. Smale, What About Shareowners' Respoinsibility?, Wall St J 24 (Oct 16, 1987) ("by focusing on the short term, our publicly held business enterprises will see their competitive position decay"); Alan Greenspan, Takeovers Rooted in Fear, Wall St J 28 (Sept 27, 1985) ("Excessively high discount factors place a disproportionate share of the value of a company's stock on near-term earnings and dividend flows.").

${ }^{62}$ See note 28 and accompanying text.

Bs See notes 29-32 and accompanying text.

4. Shleifer and Vishny, 80 Am Econ Rev Pap \& Proc at 148 (cited in note 32).

${ }^{65}$ Id at 153.

${ }^{68}$ LeRoy, $27 \mathrm{~J}$ Econ Lit at 1616 (cited in note 30 ). 
high discount rate for future earnings estimates. Jeremy Stein cites "informational asymmetry" as leading to undervaluation of productive assets that do not contribute to current earnings, forcing managers to take short-term steps such as selling the asset or leveraging against it in order to "signal" the value of the asset."

The anecdotal evidence, particularly in connection with the reaction of share prices to short-term earnings, also supports the view of a short-term bias in the market. Recent examples include Tambrands Inc., whose share price dropped precipitously on the announcement of a capital spending and marketing program that caused analysts to reduce 1990 and 1991 earnings estimates. An investment banker explained, "Some of their marketing programs were just a little more long-term in nature' than had been expected. . . . 'Some analysts were expecting more immediacy in terms of earnings growth." "68 Similarly, Motorola Inc.'s share price plunged following the announcement of lower-than-expected earnings for the third quarter of 1990, due primarily to substantial research and development expenses, notwithstanding the fact that Motorola's historical strategy of investing for the future had "helped move it from an old-line television and radio maker in the 1950 s and 1960s into a global leader in wireless communications." 69 An 83-year old investment manager, who had been investing in Motorola since 1955, said he had seen the mistake before: "I have never tried to pinpoint the exact amount of quarterly earnings ahead,' he said. 'That's not important to me." "'o Given the dominance of institutional shareholdings, these market reactions are clearly an indication of the institutional stockholders' response to these short-term earnings declines. A report on Warren Buffett's investment in Wells Fargo Corporation highlighted the scarcity of long-term institutional investors when it quoted a broker who said, "Buffett is a long term investor with a three to five year time horizon-a time frame that most institutional investors can't afford."11

Disagreeing with the assertion that institutional shareholders hold a short-term perspective, a study commissioned in the United (1988).

67 Jeremy C. Stein, Takeover Threats and Managerial Myopia, 96 J Pol Econ 61, 62-63

6s Lourdes Lee Valeriano, Estimates Lowered for Tambrands; Share Price Sags, Wall St J A10 (Nov 16, 1990).

o8 Robert L. Rose, Motorola Profit Report Depresses Stock, Wall St J A8 (Oct 10, 1990).

${ }^{70}$ Id.

${ }^{71}$ Buffett's Stake in Wells Fargo Doesn't Mean Stock's Bottomed, Portfolio Letter 3 (Oct 29, 1990). 
Kingdom by the Institutional Fund Managers' Association argues that managers and directors themselves generate a short-term outlook, in part because they wrongly believe that institutional investors share this bias. ${ }^{72}$ While evidence of the actual short-term bias of institutional stockholders is strong, the adverse consequences of short-termism may flow just as easily from a perceived short-term bias. To the extent the quinquennial proposal outlined in Part IV can promote a continuing dialogue between managers and institutional stockholders, any misperceptions that exist can be minimized.

The focus on the short term has come at the expense of the long-term planning, investment and business development of the corporation. When managers seek to boost the short-term earnings and stock price, the easiest expenditures to forego are investments in the future. Thus, corporations have sacrificed research and development expenses, capital expenditures, market development, and new business ventures, simply because they promise to pay off only in the long term. ${ }^{73}$ David Walker of the Bank of England points to "an attitude that attention to the longer run is a luxury and risk that can be indulged only within tight limits, especially by companies that see themselves as potential takeover targets." ${ }^{44}$ Instead, managers channel resources to projects expected to produce immediate results, or to financial measures, such as stock repurchase programs, designed to boost short-term earnings. The long-

72 Paul Marsh, Short-Termism on Trial 50-53 (Institutional Fund Managers' Association, 1990).

${ }^{73}$ See $R \& D$ Spending Growth Continues to Slow, Res Tech Mgmt 2 (Mar-Apr 1990) (period from 1980-85 saw annual rate of increase in American corporate research and development spending of $8.2 \%$, while period from $1985-90$ shows real increases averaging less than one-fifth that rate); NSF Implicates LBOs in Corporate R\&D Cuts-Others Not So Sure, Res Tech Mgmt 2 (May-June 1989) (National Science Foundation's 1987 survey indicates that acquisitions, mergers, and other restructurings hurt the research and development performance of those industries in which they occurred); Bronwyn H. Hall, The Impact of Corporate Restructuring on Industrial Research and Development, in Martin Neil Baily and Clifford Winston, eds, Brookings Papers on Economic Activity: Microeconomics 1990 85, 123 (Brookings, 1990) ("Regardless of whether one believes that leverage is efficiency enhancing or that it leads to a decline in productive investment, the link between leverage and reduced $\mathrm{R} \& \mathrm{D}$ spending has been established."). But see Margaret Mendenhall Blair, A Surprising Culprit Behind the Rush to Leverage, Brookings Rev 19 (Winter 1989/90) (citing high real interest rates, rather than short-term bias, as chief deterrent to new investment and chief cause of shift to debt financing). It is unclear, however, whether interest rates would have been so high during the 1980s but for the speculative binge of which the takeover and leveraging wave was a part.

" David Walker, Capital Markets and Industry, Bank of England Q Bull 573 (Dec 1985), quoted in Morgan and Morgan, The Stock Market and Mergers in the United Kingdom at 94-95 (cited in note 30 ). 
term adverse effect of these measures on the ability of our corporations to compete against business enterprises whose ownership structures, and whose countries' economies, promote investment in the future is apparent and becoming more severe.

In his monumental study of global competition, Michael $\mathrm{E}$. Porter identifies the growth of institutional investors in the United States to a position of dominance over the major business corporations as the most significant factor in the decline of American industry:

Unlike institutional investors in nearly every other advanced nation, who view their shareholdings as nearly permanent and exercise their ownership rights accordingly, American institutions are under pressure to demonstrate quarterly appreciation. Pension consultants have grown up that collect fees by assisting funds in changing asset managers whose recent performance is deemed inadequate. Asset managers, in turn, reward their employees based on the appreciation of their portfolio in the last quarter or year. With a strong incentive to find companies whose shares will appreciate in the near term and incomplete information about long-term prospects, portfolio managers turn to quarterly earnings performance as perhaps the single biggest influence on buy/sell decisions.

Managers have become preoccupied with heading off takeovers through boosting near-term earnings or restructuring. While restructuring has often led to beneficial sales of underperforming assets, cost cutting, and sometimes the weeding out of poor managements, the completion of restructuring starts the same pressures running again. The taking on of substantial debt in the course of restructuring, with proceeds paid to shareholders instead of invested in the business as was the case in highly leveraged Japanese companies, often leads to risk aversion and a slowing of true strategic innovation..$^{75}$

The focus on the short term has also led to the overleveraging of our economy. ${ }^{76}$ The last decade saw an unprecedented wave of 1990).

${ }^{76}$ Michael E. Porter, The Competitive Advantage of Nations 528-29 (Macmillan,

76 See Farrell, Bus Week at 84 (cited in note 44) (There "is growing evidence that steep leverage is beginning to hobble management, a worrisome trend because Corporate America, in this decade, has retired nearly $\$ 500$ billion in equity while piling on almost $\$ 1$ trillion in debt."). While determining the "right" level of debt is difficult, the leveraging wave of the last decade is particularly disturbing in that, historically, in times of economic expansion, 
leveraged transactions, in the form of debt-financed acquisitions, leveraged buyouts, and leveraged recapitalizations. These transactions resulted in large measure from the demand for short-term stock premiums, regardless of the long-term consequences. In the rush to profit from leveraging or breaking up the corporation, acquirors and stockholders ignored the long-term implications of these actions. Leveraged transactions allow the acquiror to pay a premium to acquire a corporation using the corporation's own assets as collateral. They allow the corporation to boost short-term value by paying stockholders a large special dividend, or to boost short-term stock prices by repurchasing a large portion of its stock. But these leveraged transactions also exacerbate the need to cut expenditures and future investments in order to produce shortterm cash flow, and leave our corporations less able to weather economic downturns. The bankruptcies and workouts now in the news are the legacy of these leveraged transactions. ${ }^{77}$

The increasing activism of institutional stockholders may well worsen the corporations' preoccupation with the short term. Influential groups such as the Council of Institutional Investors, the California Public Employees' Retirement System (CalPERS), and the United Shareholders' Association have historically promoted takeovers. Organized by these groups, large numbers of institutional stockholders have increasingly embarked on proxy voting agenda designed to remove takeover defenses and other impediments to takeover premiums. ${ }^{78}$ While takeover defenses have no intrinsic merit, they often provide the only means by which a cor-

debt levels have decreased, providing a cushion for the next downturn. See Henry Kaufman, The Great Debt Overload Will Keep the Recovery Feeble, Fortune 23 (Dec 31, 1990) ("The credit quality of American corporations deteriorated throughout the just-ended business expansion. That is unprecedented; normaily the financial condition of business improves when the economy grows.").

${ }^{77}$ See Business Failures Increase $14.5 \%$ in First 9 Months, Wall St J B2 (Nov 2, 1990) (recent report by Dun \& Bradstreet indicates that United States business failures rose $14.5 \%$ in the first nine months of 1990, to 43,836); Sharon Reier, A Banquet for Fat Cats: Bankruptcy, Financial World 36 (Oct 16, 1990) (blaming LBOs for the fact that the past two years have produced 13 of the nation's 25 largest bankruptcies, accounting for close to $\$ 50$ billion in assets); Daniel Wise, Workouts, Bankruptcy Work Replacing Junk Bonds Practices, NY L J 1 (Nov 2, 1989); Fred R. Bleakley, Many Firms Find Debt They Piled On in 1980s Is a Cruel Taskmaster, Wall St J A1 (Oct 9, 1990) (belt tightening engendered by debt load is forcing cutbacks in capital expenditures, new ventures, and new product lines, and could deepen the unfolding slump in the United States economy).

${ }^{78}$ See Investor Responsibility Research Center, Inc., Major 1990 Corporate Governance Shareholder Proposals (Feb 20, 1990) (on file with U Chi L Rev) (listing by sponsor proposals to redeem rights plans, opt out of state antitakeover laws, prohibit greenmail, ban golden parachutes, reduce supermajority requirements, etc.). 
poration and its directors and managers can seek to protect the long-term business needs of the enterprise against the pressure for short-term premiums. To the extent these defenses are removed without taking steps to reorient the stockholders' perspective to the long term, the ill effects of the current short-term bias will be exacerbated.

Similarly, CalPERS and the United Shareholders' Association have proposed comprehensive revisions of the SEC's proxy rules, intended to increase the role of institutional investors in the proxy process and corporate governance. ${ }^{79}$ Any reform in this area, however, must be part of a larger effort to reorient stockholders toward a long-term perspective. Otherwise, the increased activism of institutions in the proxy process is likely to promote a continued shortterm outlook, with all its negative consequences. ${ }^{80}$

\section{Hostile Takeovers and Short-Termism}

The hostile takeover wave of the last decade both caused and resulted from stockholders' short-term bias. A dominant stockholder population anxious to accept a takeover premium encourages the hostile acquiror with the likelihood that a premium bid will succeed or that a higher bid will prevail, allowing the first potential acquiror to profit on shares of the corporation it purchased prior to making its bid. Moreover, the short-term bias tends to result in greater discounting by the market of the long-term profits of the firm, leaving the market valuation of the corporation well below the true value of the enterprise. The acquiror is thus able to make a bid that is below the corporation's value (measured in terms of the future income streams but discounted at a lower rate than that typically produced by the short-term bias). Yet the bid,

70 See letter from CalPERS to Linda C. Quinn, Director, Division of Corporation Finance, Securities and Exchange Commission (Nov 3, 1989), reprinted in Institutional Investors: Passive Fiduciaries to Activist Owners 454 (PLI, 1990); letter from United Shareholders' Association to Edward H. Fleischman, Commissioner, Securities and Exchange Commission (Mar 20, 1990), reprinted in id at 485. Compare letter from The Business Roundtable to Linda C. Quinn, Director, Division of Corporation Finance, Securities and Exchange Commission (Dec 17, 1990) (on file with U Chi L Rev) (opposing revisions to the proxy rules).

so Philip R. Lochner, Jr., Commissioner, Securities and Exchange Commission, Improving Corporate Governance for the Nineties: The Role of Institutional Investors and Proxy Reform 6 (speech to City Club, Sept 20, 1990) (on file with U Chi L Rev) (If proposed proxy reforms are adopted and provide institutional stockholders with greater power to influence boards, institutions might "use their newfound muscle . . . to break up and sell off companies in order to yield higher short-term returns."). 
so long as it is at a premium to the market, is likely to be well received by stockholders.

At the same time, takeover activity has fueled the short-term orientation of institutional stockholders. Takeover premiums provide the fast return on financial equity investments that institutional stockholders desire. Support of hostile takeover activity has provided a focal point for the expression of short-term interests, exemplified by the spate of stockholder-sponsored proxy proposals in opposition to rights plans and other takeover defenses. ${ }^{81}$ And the threat of hostile takeovers fuels the pressure on directors and managers to increase short-term earnings and cash flow, regardless of the impact on long-term business planning and development.

The hostile takeover activity of the last decade has also imposed severe dislocations and costs on the corporation's non-stockholder constituencies. A hostile takeover often brings with it staff reductions and layoffs. It may involve selling off operating units or shutting down offices or operations. These actions frequently harm the communities affected. ${ }^{82}$ The hostile takeover may also contract the relevant product market, causing disruptions or dislocations for customers and suppliers. These costs, while not by themselves dispositive, add further weight to the case for corporate governance reforms that will discourage the reemergence of takeover mania.

\section{The Interests of Other Constituencies}

Largely in response to the impact of hostile takeover activity on the corporation's non-stockholder constituencies, twenty-nine state legislatures have enacted legislation permitting boards of directors to consider and act on the interests of these various corpo-

\footnotetext{
${ }^{81}$ See Investor Responsibility Research Center, Inc., Major 1990 Corporate Governance Shareholder Proposals (cited in note 78); Emile Geylein and Richard Koenig, Pension Funds Plot Against Takeover Law, Wall St J Cl (Apr 5, 1989) (describing attempts of three large pension funds, through stockholder proposals, to cause corporations to opt out of Delaware antitakeover statute).

${ }_{82}$ See, for example, Susan C. Faludi, Safeway LBO Yields Vast Profits but Extracts a Heavy Human Toll, Wall St J A1 (May 16, 1990) (following Safeway's defensive LBO, 63,000 workers and managers were laid off); George Anders, Morgan Stanley Found A Gold Mine of Fees By Buying Burlington, Wall St J A1 (Dec 14, 1990) (highly leveraged takeover of Burlington Industries, Inc., to rescue the company from the advances of corporate raider Asher Edelman, resulted in the selling off of twenty of Burlington's businesses and the shrinking of Burlington's work force from 44,000 before the bid to 27,500 several years later); Shleifer and Summers, Breach of Trust in Hostile Takeovers in Auerbach, ed, Corporate Takeovers at 50-51 (cited in note 34) (describing community costs to Youngstown, Ohio s. llowing acquisitions of Youngstown Sheet and Tube and Lykes Steamship Company).
} 
rate constituencies. ${ }^{83}$ Some have criticized these statutes on the basis that they call upon directors to set social policy, a task beyond the directors' proper powers. ${ }^{84}$ Constituency statutes, however, should not be viewed as giving directors a mandate to make social policy. Rather, they merely permit directors to take into account the interest and role of non-stockholder constituencies in the corporation's long-term vitality. Suppliers, customers, employees and communities all prosper in the long run if the enterprise prospers in the long run: suppliers retain a strong consumer of their products, customers retain a strong producer of desired goods or services, employees retain a healthy employer, and communities retain a vital contributor to their economic and fiscal health. Constituency statutes empower a board of directors to consider these interests in adopting a "just say no" response to a takeover bid: if the board determines that it best serves the corporation's longterm interests to remain independent, it can refuse to remove impediments to the bid.

Constituency statutes, then, are best understood as a means of permitting boards of directors to consider the interests of the corporation as a business enterprise, rather than solely the desires of the stockholders. They respond to the divergence of the stockholders' interests and the corporation's interests resulting from the separation of ownership and management and from the dominance of institutional ownership. They are, however, at best a stopgap measure. The real need is for a realignment of the interests of stockholders and corporations around the long-term health of the business enterprise. In the next Part, we seek better models for carrying out this task.

\footnotetext{
ss The concept that the interests of non-stockholder constituencies should be taken into account in the takeover context was developed in academic literature and case law prior to the enactment of constituency statutes. See, for example, Martin Lipton, Takeover Bids in the Target's Boardroom, 35 Bus Law 101, 130 (1979); Unocal Corp. $v$ Mesa Petroleum Co., 493 A2d 946, 955 (Del 1985). For examples of constituency statutes following this concept, see Ill Ann Stat ch 32, § 8.85 (Smith-Hurd Supp 1990); NJ Stat Ann § 14A: 6-1 (West Supp 1990); NY Bus Corp Law $\S 717$ (Law Co-op Supp 1989); 15 Pa Cons Stat Ann $\S$ 1721(c) (Purdon Supp 1990).

"See, for example, Committee on Corporate Laws, Other Constituencies Statutes: Potential for Confusion, 45 Bus Law 2253, 2270 (1990) ("[A]llocations of wealth (which essentially a balancing of the interests of various constituencies would be) are political decisions" which are "beyond the general pale of [directors'] perceived mandate from society.") (emphasis in original). See also Amanda Acquisition Corp. $v$ Universal Foods Corp., 877 F2d 496, 500 \& n 5 (7th Cir 1989) (Easterbrook) (no policy need to protect non-stockholder corporate constituencies, because acquiror is no more likely than incumbent management to injure these constituencies).
} 


\section{The Realignment of Interests: Lessons From HOME AND ABROAD}

A long-term view on the part of stockholders and managers is necessary to permit public corporations in the United States and the United Kingdom to invest in the future, maintain their vitality, and compete in the world economy ${ }^{85}$ Corporations must be permitted to sacrifice some immediate value to investments in capital assets, research and development, new ventures, or market share. To the extent the corporation is not permitted to invest in the future, it will inevitably lose customers and profits to those corporations that are permitted to do so. ${ }^{86}$ In this Part, we discuss elements of the Japanese and German systems of corporate governance, and the "patient capital" approach of American investor Warren Buffett, to demonstrate the advantages of long-term emphasis.

\section{A. The Need for a Long-Term View}

The long-term health of the business enterprise is ultimately in the best interests of stockholders, the corporation's other constituencies, and the economy as a whole. The institutional stockholder typically invests in a large number of stocks whose overall performance, like that of index funds, tends to mirror the performance of the market and the economy. ${ }^{87}$ Moreover, the large institu-

8s Brady, Remarks before the Business Council at 2 (cited in note 6) (American corporations "can't innovate and produce the products needed to capture world markets by focusing on results one quarter at a time."); Alan O. Sykes, Corporate Takeovers-the Need for Fundamental Rethinking 21 (David Hume Institute, 1990) ("The inevitable consequence of 'City' short-termism is long-term damage to the City on the back of far greater long-term damage to the [United Kingdom's] corporate sector as a whole."); Lord Alexander of Weedon, Q.C., Chairman of National Westminster Bank'and former Chairman of the City Takeover Panel, The Changing Nature of Finance 9 (speech for the Lombard Association 60th Anniversary Dinner, Oct 4, 1990) (on file with U Chi L Rev) ("Concern about takeovers may inhibit medium- to long-term planning and, as some say, research and development. The future of companies may undoubtedly be settled on the basis of short-term considerations.").

${ }^{86}$ See, for example, John J. Curran, Hard Lessons from the Debt Decade, Fortune 76 (June 18, 1990) ("Says Douglas Watson, head of industrial ratings at Moody's Investors Service: 'I've been seeing signs that once a company leverages, it invites predatory behavior from its rivals.' For example, most major supermarket chains are stocked to their fluorescent lights with debt. Thus they're in no shape to respond as A\&P, one of the few grocers with a clean balance sheet, aggressively expands into their markets.").

87 Gilson and Kraakman, Reinventing the Outside Director at 6-8 (cited in note 1) (institutional investors increasingly "hold the market," whether through indexing or simply by virtue of the size of their portfolios, thereby eliminating the likelihood of benefits from active trading). 
tional stockholder is a long-term investor in the market as a whole. Unless it divests itself of equities altogether, it will have an equity stake in a substantial portfolio of corporations regardless of how long it maintains a stake in any one corporation. To the extent the economy as a whole thrives over the long term, the portfolio should thrive, regardless of the performance of, or the availability of takeover premiums for, any individual stock.

Professors Gilson and Kraakman cite several studies for the proposition that takeovers provide long-term benefits to stockholders. "[O]n average," they claim, "target shareholders lose significantly when offers are defeated and the company is not subsequently acquired by an alternative bidder. ... [T] he data resolves the charge that a favorable orientation to premium tender offers reflects a short-term orientation."88 It is unclear, however, why one should limit the sample to companies "not subsequently acquired by an alternative bidder." The corporation that defeats a takeover bid retains the value of control, on which it may realize a premium by selling the corporation at any time. The corporation that is acquired, of course, loses the asset of control.

More importantly, all the studies cited by Professors Gilson and Kraakman necessarily measure stock market effects within the existing system of corporate governance. In the current environment, corporations that successfully defeat a takeover attempt (as well as corporations seeking to avoid a takeover attempt) may take steps to boost short-term earnings or value whether or not these steps are in the long-term interests of the corporation. The studies cannot measure the benefits of a new system that would encourage all the corporation's constituencies to work toward the long-term success of the corporate enterprise. It may well be rational under the current system for any individual investment manager to focus on short-term results, ${ }^{89}$ but the short-term bias remains irrational for the economy as a whole.

The takeover activity of the last decade did not enhance the development of productive assets. Instead, it produced a reshuffling of assets, large gains to the sponsors of and advisors to the reshuffling, large gains (and losses) to the arbitrageurs who bet on the outcome of the transactions, substantial societal dislocations, and a legacy of heavy debt burdens. ${ }^{90}$ In some cases takeovers did

ss Id at 11 \& $n 16$.

see text at notes 55-60.

- Lester C. Thurow, Let's Put Capitalists Back into Capitalism, Sloan Mgmt Rev 67, 68 (Fall 1988) (lack of productivity growth during takeover era demonstrates that acquisi- 
shift assets to more efficient uses, but the studies that claim takeovers generally have this positive effect tend to measure very short time spans, not long-term effects. ${ }^{91}$ Even some proponents of hostile takeovers doubt that they are the best way to bolster the longterm health and productivity of our corporate economy. ${ }^{92}$ The healthy economies of Japan and Germany result in large part from effective, stable management and long-term capital investment. ${ }^{93}$ Unless the corporate governance systems of the United States and the United Kingdom can engender a similar long-term orientation, the relative health of American and British corporations, and the relative wealth of their stockholders, will inevitably erode.

The following illustrations are not intended to imply that either the Japanese or German corporate regime can or should be transplanted to the American or British corporate setting. Rather, these examples are meant to demonstrate successful alternatives to the managerial discipline model of corporate governance.

\section{B. Japan and Germany}

There are many reasons for the economic health and success of Japan and Germany relative to the United States and the United Kingdom. ${ }^{94}$ It is not possible, of course, to determine pre-

tions are a redistributive activity, not a productive activity); Stout, 99 Yale L J 1235 (cited in note 32) (takeover premiums may be a natural market phenomenon rather than evidence of efficiency gains).

${ }^{21}$ See, for example, Gregg A. Jarrell, James A. Brickley, and Jeffrey M. Netter, The Market for Corporate Control: The Empirical Evidence Since 1980, 2 J Econ Persp 48, 66 (1988) ("premiums in takeovers represent real wealth gains.and are not simply wealth redistributions"); Michael C. Jensen, The Takeover Controversy: Analysis and Evidence, Midland Corp Fin J 6, 6 (1986) (attributing takeovers to "productive entrepreneurial activity that improves the control and management of assets and helps move assets to more productive uses").

${ }^{22}$ See, for example, Gilson and Kraakman, Reinventing the Outside Director at 14 (cited in note 1) ("the hostile takeover is an expensive and inexact tool for monitoring managers that is better suited for correcting mistakes than preventing them").

${ }^{\circ}$ See Evan Herbert, How Japanese Companies Set R\&D Directions, Res Tech Mgmt 28 (Sept-Oct 1990) (Japanese corporate governance system enables corporations to suffer prolonged losses until R\&D pays off); Brian O'Reilly, America's Place in World Competition, Fortune 80 (Nov 6, 1989) (In 1987, Japan's capital spending was approximately 22 percent of GDP, West Germany's was approximately 17 percent of GDP, and the United States' and the United Kingdom's were approximately 13 percent of GDP.).

94 Factors that have been cited include higher levels of saving, lower costs of capital, and cultural work ethics. See generally G.C. Allen, The Japanese Economy (St. Martin's, 1981) (emphasizing the importance of political and social factors in Japan's economic growth); Porter, The Competitive Advantage of Nations at 368-82 (cited in note 75) (education, research, and worker commitment, as well as corporate governance structure and nature of capital markets, contributed to German economic success). 
cisely the degree to which any given factor has contributed to this success. Many commentators agree, however, that an important factor is their corporate governance schemes. ${ }^{95}$ At a minimum, Japan and Germany provide notable examples of alternatives to the managerial discipline model of corporate governance, chosen by two countries whose modern economies have been among the most successful in the world. Japan and Germany have created systems akin to what has been termed "proprietor-capitalism," the sort of capitalism envisioned by classical economic theory, in which stockholders are knowledgeable and actively involved in ensuring the quality of management. ${ }^{.6}$ These systems stand in contrast to the "punter-capitalism" of the United States and the United Kingdom, in which stockholders typically remain uninvolved in assessing and developing the business operations and management of their corporations, except when it comes to the opportunity to receive the short-term premium of a takeover. ${ }^{97}$

\section{Japan: Control through the keiretsu.}

The Japanese model centers around the keiretsu, a voluntary grouping of firms and financial institutions with cross-shareholdings and business relationships:

[Members of the keiretsu] hold non-controlling stock in each other's firms. In addition, shares are owned by banks and life insurance companies with the expectation of assured longterm business relationships. In Japan, corporations and financial institutions together hold about two-thirds of all stock listed on all exchanges. Often the majority of shares in a corporation are collectively owned by members of the same industrial group or keiretsu. ${ }^{98}$

This cross-shareholding, together with major shareholdings by the corporation's lenders, provides stability and a long-term orientation for Japanese corporations, leaving roughly 25 percent of

9s See, for example, Capitalism at 17 (cited in note 10); Sykes, Corporate Takeovers at 12-13 (cited in note 85); Dertouzos, Lester, and Solow, Made in America at 61-62 (cited in note 46); Brady, Remarks before the Business Council (cited in note 6); Jonathan Charkham, The American Corporation and the Institutional Investor: Are There Lessons From Abroad? Hands Across the Sea, 1988 Colum Bus L Rev 765, 766.

96 Capitalism at 7 (cited in note 10).

97 Id.

98 Aron Viner, Mergers, Acquisitions and Corporate Governance in Japan, in Joseph C.F. Lufkin and David Gallagher, eds, International Corporate Governance 27 (Euromoney Books, 1990). 
shares available for everyday trading. ${ }^{99}$ The concentration of shareholdings creates a monitoring body that can assess the business performance of the corporation and its managers. ${ }^{100}$ But the business relationships among the keiretsu, primarily lending, customer, and supplier relationships, ensure the alignment of interests around the long-term business health and vitality of the corporation. This structure insulates the management of Japanese corporations against the short-term pressures felt by managers in the United States and the United Kingdom. ${ }^{101}$

\section{Germany: Control through bank intermediation.}

While quite different from that of Japan, the German corporate governance structure leads to the same result. Stock ownership of public corporations in Germany is largely through bank intermediaries that vote the shares they hold for others. Voluntary delegation of voting rights to portfolio-managing banks is the norm among private investors, except for major stockholders. For widelyheld corporations these banks account for over 90 percent of voting rights, with the three largest banks controlling the voting rights of over 40 percent of all shares. ${ }^{102}$ The banks also own shares in their own right and often hold seats on corporate supervisory boards,

98 Capitalism at 17 (cited in note 10). See also Tony Shale, Reawakening the Sleeping Giant, Euromoney 14, 17 (Nov 1990) ("of the 1,612 companies presently listed on the Tokyo Stock Exchange, 1,100 belong to keiretsu groupings and account for $78 \%$ of market capitalisation").

${ }^{100}$ See Ramseyer, 35 UCLA L Rev at $49-50$ (cited in note 34) (Japanese shareholders have greater incentive to monitor managers as they generally hold large blocks of stock due to the cross-shareholding practices in Japan. In addition, Japanese banks have proved to be effective monitors of the corporations with which they have ongoing financial dealings.).

101 See id at 21-32 (Several factors combine to make hostile acquisitions in Japan a relatively unprofitable, and therefore, rare occurrence: (1) the practice of cross-shareholding in corporation stocks increases the cost of obtaining a controlling block of shares; (2) the higher leverage of Japanese firms gives the lending bank the ability to bargain with the potential acquiror for a portion of the gains; and (3) the absence of a provision in Japanese law allowing the acquiror to cash out minority shareholders after the bid permits shareholders to free-ride on any efficiency gains resulting from the acquisition.). See also Martin Lipton, Paying the Price of Takeover Money 34, Manhattan, inc. (May 1989) (quoting a 1988 speech by Masaaki Kurokawa, the chairman of Nomura Securities International: "Japanese top management need not concentrate on short-term-profit schemes for the sole purpose of appeasing its investors. In the United States, by contrast, each quarter's profit statement brings around renewed panic or exaltation, as investors concentrate on short-term results rather than long-term profit and investment. Japan's separation of management and investors, however, allows freer investment in long-term physical assets, which, of course, contributes to Japan's strong economic performance.").

102 Hermann H. Kallfass, The American Corporation and The Institutional Investor: Are There Lessons From Abroad? The German Experience, 1988 Colum Bus L Rev 775, 782-83. 
adding to their enormous power. ${ }^{103}$ Like the keiretsu, the German structure insulates management from short-term pressures. It concentrates the control of shareholdings within a group capable of effective monitoring, but oriented toward the long-term business health of the corporation. ${ }^{104}$

\section{Applicability of the Japanese and German examples.}

Even if we favored the full-scale transplantation of the Japanese or German models into the Anglo-American corporate environment, which we do not, we recognize that present antitrust and banking statutes would forbid it and that the American and British political systems would probably reject the concentration of corporate power in such small groups. ${ }^{105}$ But some of the concepts of the Japanese and German structures can be applied to the American and British systems. Professors Gilson and Kraakman describe the Japanese and German structures as the "banker model." They dismiss the banker model as "inapposite to the circumstances of the American institutional investor," claiming that it "unifies, rather than bridges, ownership and control."106

${ }^{103}$ Id at 783 ("It is hardly possible for private investors to effectively control the exercise of voting rights by banks, and in practice they do not do so. This enables banks to pursue their own interests when exercising voting rights, for instance, voting with a view to their lending or investment business."); Dirk Schmalenbach, Federal Republic of Germany, in Lufkin and Gallagher, eds, International Corporate Governance at 109, 111 (cited in note 98) ("As a general rule the banks tend to exercise their power in support of management which ... will often make shareholder activism and attempts by shareholders to maximise shareholder value in a way which is contrary to the present policy of management, seem futile. ... In their role as lenders the banks prefer a long-term increase in the substance of the company rather than the distribution of high yield dividends.").

106 See, for example, Kallfass, 1988 Colum Bus L Rev at 790-91 (cited in note 102) ("Bank representatives are thus involved in filling positions on managing boards and in making important business decisions. The resulting stability of control reduces the pressures on managers, freeing them to pursue medium to long-term corporate objectives."); Porter. The Competitive Advantage of Nations at 376 (cited in note 75) ("Sustained commitment to the business is reinforced by the nature of German capital markets. Many company shares are held by banks and other long-term holders, who often play a prominent role on boards. . . . The concern for quarterly earnings, in preference to actions required to sustain the long-term position, has been all but absent, in contrast to the United States."); Andrew Fisher, Banks Facing Up to Foreign Competition, The Banker 22, 39 (Apr 1987) ("The country's two biggest banks, Deutsche and Dresdner, played important roles in the nursing back to health of Germany's largest shipping group, Hapag-Lloyd. . . . At AEG, the electrical and electronics giant now controlled by Daimler-Benz, banks were also instrumental in preventing a collapse into bankruptcy.").

${ }^{205}$ See Gilson and Kraakman, Reinventing the Outside Director at 28 \& $\mathbf{n} 52$ (cited in note 1) (noting political and cultural barriers to use of Japanese and German structures in the United States and United Kingdom).

108 Id at 27. 
The German banks and the Japanese keiretsu, however, constitute monitors, not managers, of the public corporation. Ownership and management remain separate, but the structure of stock ownership ensures the alignment of the interests of the managers and stockholders around the long-term interests of the business enterprise, and creates a stockholder presence capable of shielding management from short-term pressures and monitoring managerial performance. There is no reason that the systems of the United States and United Kingdom cannot be reconstructed, by far less radical means, to serve the same goals: alignment of stockholder and corporate interests around the long-term health of the corporation as a business enterprise, insulation of management from short-term financial pressures, and effective monitoring of the long-term business performance of the corporation's managers.

\section{Leveraged Buyouts}

In the United States and the United Kingdom, the replacement of public with private ownership structures, particularly through leveraged buyouts (LBOs), has become a common means of reuniting ownership and management, and has been cited as a means of improving corporate efficiency. ${ }^{10 z}$ Substantial equity stakes for managers, active monitoring by the LBO sponsor/investor, and freedom from the preoccupation with reported quarterly earnings and takeover defenses often combine to cause substantial improvement in the newly private corporation's business operations. ${ }^{108}$ The financial incentives and risks for the management of the post-LBO corporation can motivate quite effectively: the manager who takes personal loans, perhaps even mortgages his house, to participate in the equity of a buyout has a more direct financial stake in the corporation's success than the manager who is insulated from personal financial risk.

\footnotetext{
${ }^{107}$ Michael C. Jensen, Eclipse of the Public Corporation, Harv Bus Rev 61, 65 (SeptOct 1989) ("[T]hese organizations' resolution of the owner-manager conflict explains how they can motivate the same people, managing the same resources, to perform so much more effectively under private ownership than in the publicly held corporate form."); Frank H. Easterbrook and Daniel R. Fischel, Corporate Control Transactions, 91 Yale L J 698, 706 (1982) (when firms go private they eliminate or substantially reduce the separation of ownership and control).

${ }_{108}$ See, for example, Brett Duval Fromson, Life After Debt: How LBOs Do It, Fortune 91 (Mar 13, 1989) (describing how O.M. Scott \& Sons, Borg-Warner, and other companies substantially improved their operating performances in response to the pressures and opportunities created by LBOs).
} 
The current recession demonstrates, however, that LBOs also entail enormous risks for corporations and the economy as a whole. Overleveraging engendered by the LBO wave has left many corporations in dire straits as the economic growth of the 1980s has slowed or reversed. ${ }^{108}$ Even those newly private corporations that are not facing bankruptcy often find that massive debt and interest payments siphon off the cash they need to invest in productive uses. The debt burden of the LBO arguably forces managers to operate efficiently in order to meet their payments. ${ }^{110}$ But LBO debt imposes a decidedly short-term discipline. Lenders in an LBO, unlike the lender/stockholders of the German and Japanese systems, are attracted by the initial transaction fees and seek a quick repayment of their loans. ${ }^{111}$ The LBO thus replaces the short-termism of the institutional stockholder and the hostile takeover with the short-termism caused by the need to pay down debt quickly.

Even proponents of the LBO as a promoter of efficiency recognize that "the LBO capital structure is simply inappropriate ... for large numbers of public corporations that require the cash flow flexibility to fund [research and development] or to compete in growing markets."112 Moreover, the corporation taken private in an LBO typically goes public again within a matter of a few years. ${ }^{113}$ Indeed, taking the LBO company public is the only way the LBO investor can realize the $30-40$ percent annual equity returns promised by LBO sponsors. Returns at that level depend on high leverage and quick resale of the equity. Thus, the LBO does not offer a widely applicable, long-term answer to the problems of corporate governance.

\section{Patient Capital}

A more promising model for the United States and the United Kingdom is the "patient capital" philosophy exemplified by Warren Buffett and Berkshire Hathaway, of which Mr. Buffett is chairman. Like the LBO sponsor and management investor, Mr. Buffett

100 See sources cited in note 77.

110 Jensen, Harv Bus Rev at 66-67 (cited in note 107).

211 See Staff of House Subcommittee on Oversight and Investigations of the Committee on Energy and Commerce, 101st Cong, 1st Sess, Leveraged Buyouts and the Pot of Gold: 1989 Update 148 (Committee Print, 1989) (testimony of L.W. Seidman, FDIC Chairman) (substantial origination fees and selling fees are significant inducements to banks' competition to lend for LBOs).

112 Gilson and Kraakman, Reinventing the Outside Director at 25-26 (cited in note 1).

11s See Louis Lowenstein, Management Buyouts, 85 Colum L Rev 730, 731 (1985); Leslie Wayne, 'Reverse LBO's' Bring Riches, NY Times D1 (Apr 23, 1987). 
serves the role of a knowledgeable and motivated monitor for the companies in which he and his company invest. But he invests in unleveraged companies and has a time horizon far beyond that of the typical LBO investor. He treats "almost all [Berkshire Hathaway's] investments as long-term ownership commitments." 114 Mr. Buffett says: "[W]e have no interest at all in selling any good businesses that Berkshire owns, and are very reluctant to sell sub-par businesses as long as we expect them to generate at least some cash and as long as we feel good about their managers and labor relations." 115

This investment strategy has produced astonishing results. Berkshire Hathaway's return has far exceeded that of the market and almost any investment manager: "Since Mr. Buffett took over Berkshire, $\$ 10,000$ invested in its shares has grown to be worth about $\$ 1.5 \mathrm{~m}$ [illion], a compound growth rate of $23 \%$ a year."116 The patient capital approach teaches that long-term investment in successful business enterprises can provide a highly attractive return, over a much longer period, when contrasted with a preoccupation with short-term results and takeover premiums. As The Economist concludes, "Whenever a typical money manager claims that at least his betting-slip ways produce results, remind him gently of Warren Buffett." 117

\section{The Quinquennial Proposal}

In this Part we describe our proposal for reform of the American and British corporate governance systems. This proposal, the quinquennial system, seeks to make stockholders and managers think and act like long-term owners by combining the patient capital approach of Warren Buffett, the long-term monitoring approach of the Japanese and German ownership structures, and the financial incentives for managers of the LBO. The quinquennial system would permit the delegation of control of the corporation to its managers for sufficiently long periods of time to allow them to make the decisions necessary for the long-term health of their corporation. At the same time, it would force managers to develop and justify their long-term plans for the corporation, and would evaluate and compensate managers based on their ability to imple-

\footnotetext{
114 Capitalism at 15 (cited in note 10).

115 Id (quoting statements of Warren Buffett in Berkshire Hathaway Annual Report to Stockholders).

118 Id.

${ }^{117}$ Id at 16.
} 
ment those plans successfully. The system would motivate stockholders, directors and managers to work cooperatively towards the long-term business success of the corporation. And, if it ultimately became necessary, it would allow stockholders to remove incompetent or venal management and to force the sale or restructuring of the corporation if that is determined, after sufficient time and study, to be the best alternative.

The first section of this Part sketches the broad outlines of the quinquennial system. Succeeding sections provide a detailed description of each element of the proposal: the operation of stockholder meetings, the use of the proxy machinery, public reporting requirements, managerial compensation, rules governing takeovers, and the role of outside directors. The final section discusses the steps necessary to implement the system. We have presented the basic concept of the quinquennial system before. ${ }^{118}$ Here we present it in fully developed form, as a response to the concerns outlined in the preceding Parts.

\section{A. The Quinquennial Concept}

The essence of the quinquennial proposal is to convert every fifth annual meeting of stockholders into a meaningful referendum on essential questions of corporate strategy and control, and to limit severely the ability of stockholders to effect changes in control between quinquennial meetings. Stockholders would elect directors for five-year terms. Directors seeking reelection would stand on the corporation's record for the past five years and its strategic plan for the next five years. Stockholders would base their determination of whether to oppose incumbent directors, and focus any challenge they determined to mount, on the same issues. Between these quinquennial election meetings, stockholders could remove directors only for personal illegal conduct or willful malfeasance, or if the corporation were guilty of such conduct. The board would have to consent to any takeover between quinquennial meetings. Potential acquirors could, however, make unsolicited acquisition proposals in conjunction with the quinquennial meeting, in which case the meeting would become a referendum on the proposals. In connection with the quinquennial meeting, any stockholder or group of stockholders owning five percent or more of the

118 Martin Lipton, An End to Hostile Takeovers and Short-Termism, Financial Times $\S 1$ at 21 (June 27, 1990); Martin Lipton, Quinquennial Election of Directors: A Proposal for Discussion, Wachtell, Lipton, Rosen \& Katz Memorandum to Clients (Apr 9, 1990) (on file with U Chi L Rev). 
corporation's outstanding shares, or shares having a market value of five million dollars or more, would have the same access as the incumbent board to the corporate proxy machinery, in support of any candidates they wished to nominate. This access would include corporate payment of proxy contest expenses to the same extent as incumbent expenditures.

In the year of the quinquennial meeting, within 75 days after the corporation's fiscal year ends, the corporation would send to its stockholders a detailed report on its performance over the prior five years compared to its strategic plan, together with industry averages and other relevant data. The report would also detail the corporation's projections for the next five years, the assumptions underlying those projections, expected returns on stockholder investment, and the management compensation plan. At the same time, an investment bank, accounting firm, or other outside advisor selected by the board would send stockholders a detailed, independent evaluation of both the corporation's performance for the prior five years and its projections for the next five years. Stockholders would have 60 days after the mailing of the report and evaluation to decide whether they wish to nominate candidates for election as directors.

Because the quinquennial proposal would eliminate coercive takeovers, it would also eliminate the panoply of private takeover defenses and state legislation. It would make moot the issue of whether and the extent to which directors can consider non-stockholder constituencies: decisions on takeover bids would lie in the hands of the stockholders at the quinquennial meetings, and would be at the discretion of the board between meetings. It would also affirm the "one-share, one-vote" provisions currently embodied in Rule 19c-4 under the Securities Exchange Act. ${ }^{119}$ In sum, it would make the quinquennial election a true, unobstructed stockholders' referendum on the corporation's performance and plans.

The quinquennial system would strengthen the board's independence by requiring a majority of outside directors. The system would look to outside directors to provide an effective monitoring function over the operations of the corporation. The increased

11817 CFR § 240.19c-4 (1990) (Rule 19c-4 seeks to deter corporate action, including issuance of new class of securities, which "[has] the effect of nullifying, restricting, or disparately reducing the per share voting rights" of existing common stock shareholders.). But see The Business Roundtable o SEC, 905 F2d 406 (DC Cir 1990) (Rule 19c-4 invalidated because SEC exceeded its authority under the Securities Exchange Act of 1934 in adopting the Rule.). 
ability of stockholders to replace directors at the quinquennial meeting would lead directors (and, at the directors' insistence, managers) to work far more closely with major stockholders than they typically now do. To avoid the risk of replacement at the quinquennial meeting, directors would carefully monitor the corporation's progress against its long-term plan and maintain a close dialogue with stockholders with respect to the corporation's ongoing performance. Meanwhile, the five-year period between elections, and the extremely limited ability to replace directors otherwise, would leave stockholders with little choice but to work cooperatively with directors during the five-year period, within a structure that focuses all parties on the long-term business performance of the corporation.

Lack of information for outside directors, as well as lack of time or expertise to evaluate corporate information, often limits directors' ability to monitor managerial performance. ${ }^{120}$ The fiveyear report would lower the information barrier for directors as well as stockholders, and encourage managers and outside advisors to consult more often with outside directors on the corporation's performance and direction. Many corporations today present their directors with an in-depth annual review by management and outside advisors of the corporation's business plan and objectives, its historical success or failure in meeting these objectives, and the steps it plans to take in the future. The quinquennial system would encourage this type of healthy in-depth analysis.

The quinquennial system would make the corporation's fiveyear performance, including its success in meeting its five-year plan, the sole basis for incentive compensation. It would eliminate the annual or biannual incentive awards now common. Managers would receive substantial rewards, well in excess of current compensation levels, only if the corporation met or exceeded its goals. Given the increased demands on their time and resources, outside directors would receive more compensation than they now generally do, with an incentive system similar in concept to management's.

The quinquennial system would benefit the corporation's other constituencies, which prosper if the enterprise's business op-

220 See, for example, Lorsch, Pawns or Potentates at 55-58 (cited in note 19); Gilson and Kraakman, Reinventing the Outside Director at 22 (cited in note 1). See also William L. Cary and Melvin A. Eisenberg, Cases and Materials on Corporations 215-16 (Foundation, 5th ed 1980). 
erations prosper over the long term. ${ }^{121}$ Moreover, by eliminating hostile takeovers and removing the pressure for excessive leveraging, the quinquennial system would ameliorate the societal dislocations that resulted from the takeover and leveraged buyout wave of the last decade. ${ }^{122}$

At the outset, we suggest limiting the quinquennial system to large corporations, such as the Standard and Poor's 500 or the Business Week 1000, which are more heavily held by institutional investors. After experience with these corporations, the quinquennial system could then apply to a broader group.

The quinquennial proposal would not entrench directors or managers. It is not designed to prevent changes in corporate control, but rather to channel nonconsensual changes in control into a more healthy forum. The primary defect of the takeover activity of the past decade is not that it allowed for the replacement of directors and managers, but that it forced an external, short-term focus on companies, directors, managers, and their stockholders. The quinquennial system, by making the corporate proxy machinery available to substantial stockholders who wish to nominate a competing slate of directors, would actually enhance the ability of stockholders to replace incumbent directors and to change corporate strategy. But it would provide this opportunity within a framework that permits the corporation to carry out long-term plans, and permits stockholders to assess their results before deciding whether they are satisfied with their directors' performance. Removal and replacement of directors would occur by means of an orderly stockholder vote, based on full information. The quinquennial framework would thus prevent the hurried decisionmaking imposed on corporations and their stockholders in the context of hostile takeover battles ${ }^{123}$ and would eliminate the type of abusive, coercive takeover activity prevalent in recent years.

The remainder of this Part develops in more detail the elements of the quinquennial proposal and the rationale underlying each element.

121 See Part II.D.

122 See Parts II.B. and II.C.

${ }^{123}$ See 17 CFR \& 240.14e-1(a) (1990) (tender offer may be completed in as little as twenty business days). This is hardly a time frame within which to decide intelligently the destiny of the enterprise. 


\section{B. The Quinquennial Meeting}

\section{Rationale for five-year terms.}

The five-year period between election meetings affords directors and managers some measure of freedom from the short-term focus now imposed on them by institutional stockholders' pressure for quarterly results and the ever-present takeover threat. Like the four-year terms of American presidents and the six-year terms of senators-as opposed to the two-year terms served by members of the House of Representatives-it encourages a focus on long-term policy decisions. ${ }^{124}$ Yet the period is short enough that directors and managers would feel an ongoing need to report to stockholders on their plans and progress. The period is also short enough to permit development of a realistic business plan for presentation to stockholders in connection with the election meeting; five years is a common yardstick for business planning today. Annual meetings of stockholders would continue for matters other than election of directors.

The five-year time period would also give institutional stockholders enough time to evaluate managers and directors and to plan an effort to replace ineffective directors. Free access to the corporate proxy machinery and to detailed business information, in connection with the quinquennial meeting, would enable institutional stockholders to monitor effectively and knowledgeably. The election of a competing slate of directors would become a realistic and practical alternative for dissatisfied stockholders, giving directors and managers a powerful incentive to work cooperatively with stockholders throughout the period between quinquennial elections.

\section{Limited exceptions to the five-year rule.}

The five-year period would not be wholly inflexible. As noted above, the quinquennial proposal contemplates that directors would be removable by stockholders during the five-year interim in extreme cases of individual or corporate misconduct or illegality. It would also be possible to provide an "escape valve" for the unusual case where the corporation is doing so poorly that five years might be too long a period to wait for directors to come up for reelection.

124 See Gary C. Jacobson, The Politics of Congressional Elections 87-91, 216-18 (Little, Brown, 2d ed 1987); M. Kent Jennings and L. Harmon Zeigler, eds, The Electoral Process 28-29, 37-38 (Prentice-Hall, 1966) (noting flaws in political system produced by fact that incumbent Representatives usually conduct perpetual campaigns). 
For example, the holders of 20 percent of the corporation's shares could be allowed to call an election meeting during the five-year interim if the corporation failed to achieve at least 80 percent of its five-year projections for two consecutive years. Any such meeting would be subject to the same requirements as the quinquennial meeting: major stockholders would have access to the corporate proxy machinery, and the corporation would issue a detailed report together with the advisors' evaluation of that report.

But any exceptions to the five-year rule must operate only in truly exceptional circumstances, or the system would not promote the long-term perspective that is its goal. For example, there should be no exception to the five-year rule for an acquisition proposal from a third party. The incumbent board would consider any proposal made between elections and accept or reject it as the board determines appropriate. The board's determination with respect to the acquisition proposal might become an issue at the next quinquennial meeting, but not before.

\section{Access to Corporate Proxy Machinery}

1. The need to ensure meaningful elections.

The most commonly cited obstacles to effective corporate democracy are the ability of management to control the corporate proxy machinery and the cost to any one stockholder or group of stockholders of amassing the information necessary to evaluate the performance of managers and directors properly. ${ }^{125}$ The efforts of a single investor or a group of stockholders to evaluate the corporation's business or run a proxy contest may benefit all stockholders, but there is no effective means to eliminate free riders and distribute the costs among all stockholders. ${ }^{126}$ Corporate elections therefore tend to produce a realistic challenge to incumbent directors only in the context of takeover battles, fueling the contention of proponents of the managerial discipline model that hostile takeovers are needed to discipline managers and directors. ${ }^{\mathbf{1 2 7}}$

${ }^{128}$ See, for example, Eisenberg, 89 Colum I Rev at 1474-75 (cited in note 46); Jeffrey N. Gordon, Ties that Bond: Dual Class Common Stock and the Problem of Shareholder Choice, 76 Cal L Rev 3, 43-44 (1988).

${ }^{128}$ See, for example, Eisenberg, 89 Colum L Rev at 1478-79 (cited in note 46); Jeffrey N. Gordon, The Mandatory Structure of Corporate Law, 89 Colum L Rev 1549, 1575-76 (1989).

${ }_{132}$ See Edward Jay Epstein, Who Owns the Corporation? 13 (Priority, 1986) (Corporate elections are "procedurally much more akin to the elections held by the Communist party of North Korea" than real democratic elections because "they normally provide only one slate 
Corporate elections need not be a sham, however. The quinquennial meeting structure removes the chilling effect of an everpresent takeover threat on long-term planning. Once election contests are no longer simply another short-term coercive takeover tactic, they can become a meaningful referendum on the corporation's business plans and performance. The combination of free access to the corporate proxy machinery, and the provision of the detailed information contemplated by the five-year report, discussed in greater detail below, would effect this restructuring. It would also eliminate the free rider problem, by allocating the costs of the information gathering and the proxy process to the corporation and thus, effectively, to all stockholders.

The quinquennial proposal would grant free access to the corporate proxy machinery in connection with the quinquennial meeting to any stockholder or group of stockholders with at least five percent of the outstanding shares, or shares having an aggregate market value of five million dollars or more. These thresholds are high enough to exclude "gadfly" stockholders, but low enough not to impede the serious, substantial stockholder who wishes to propose nominees or a slate of directors in an election contest. Access to the corporate proxy machinery would include the corporation's payment of the challenger's proxy expenses, up to the amount that the incumbent directors spend on the proxy contest. This would place institutional stockholders on the same footing as the corporation's board with respect to nomination and election of corporate directors, thereby radically improving the ability of these stockholders to participate meaningfully in the selection of directors.

The quinquennial proposal does not, however, anticipate the frequent, wholesale replacement of directors every five years. The very credibility of the quinquennial election would lead directors and managers to develop a working relationship with the corporation's major stockholders. And once the stockholders are placed in a structure that promotes a focus on the long-term business operations of the corporation, they will be more inclined, except in extreme cases, to try to influence the incumbent directors and managers rather than risk the disruption to business operations of a wholesale change in senior personnel.

The quinquennial proposal would also eliminate SEC Rule $14 a-8$, which generally allows any holder of $\$ 1,000$ worth of a corporation's stock to require inclusion of a proposal in the corpora-

of candidates."). See also Easterbrook and Fischel, 94 Harv L Rev at 1170-74 (cited in note 1). 
tion's proxy statement. ${ }^{128}$ While intended to promote stockholder interest in corporate governance, in practice this rule has become the tool of gadflies who seek to promote special interests. ${ }^{129}$ Stockholders may espouse any cause they wish, but the corporate proxy machinery is rarely the appropriate forum for such expression.

More recently, institutional investors have also used Rule 14a8 to address voting procedures and takeover-related issues and defenses. The last few years have seen a spate of proposed stockholder resolutions dealing with rights plans, confidential voting, and golden parachutes. ${ }^{130}$ The quinquennial proposal would largely supersede this agenda by eliminating takeover defenses and limiting nonconsensual changes of control to the quinquennial meeting, at which major stockholders or groups of stockholders would have full and free access to the corporate proxy machinery. Moreover, the availability of the quinquennial meeting as a realistic means for institutional stockholders to replace directors would increase responsiveness to institutional concerns during the interim periods. Rule 14a-8, accordingly, would become unnecessary.

2. Proxy access only desirable as part of fundamental reform.

Access to the corporate proxy machinery as contemplated by the quinquennial system is desirable only in conjunction with the other elements of the proposal. Granting substantial stockholders free access (including coverage of reasonable expenses) to the corporate proxy machinery, without reorienting those stockholders away from a strictly short-term perspective, would only exacerbate the short-term pressures and detrimental effects of the takeover activity of recent years. If stockholders continue to view their investment as a gambling chip and any takeover premium as a jackpot, then the stockholders' increased ability to nominate and elect their own directors would only worsen the problems of shorttermism.

12817 CFR § 240.14a-8 (1990).

128 See, for example, Jesse H. Choper, John C. Coffee, Jr., and C. Robert Morris, Jr., Cases and Materials on Corporations 647 (Little, Brown, 3d ed 1989) (rule recently used to address issues relating to discrimination, nuclear power, pollution, and divestment from South Africa).

130 John J. Gavin, Changes in Corporate Control and Governance Communicated through Proxy Power, in Institutional Investors: Passive Fiduciaries to Activist Owners 91, 95-96 (PLI, 1990) (215 governance proposals submitted by institutional investors and voted upon at annual meetings in 1989); Dennis J. Block and Jonathan M. Hoff, Emerging Role of The Institutional Investor, NY L J 5 (Apr 12, 1990) (listing confidential voting, repeal of poison pills, and golden parachutes as top three subjects of governance proposals). 
Professors Gilson and Kraakman, for example, propose the development of a class of professional directors elected by and responsible to institutional stockholders, suggesting that these directors could be recruited and monitored by a clearinghouse initiated by one of the existing "shareholders' rights" groups such as the Council of Institutional Investors or United Shareholders' Association. ${ }^{131}$ These organizations, however, have been particularly vocal in their short-term orientation and pro-takeover bias. ${ }^{132}$ Gilson and Kraakman's proposal ignores the pressing need for directors to adopt a long-term measure of performance or success. Unless the orientation of institutional stockholders shifts away from the short term, then directors beholden to these stockholders will simply represent a potent constituency seeking a fast return. If selling or busting up the corporation generates this return, so much the better. Only when these stockholders redefine the success of their investment in terms of long-term operating returns, rather than takeover or other short-term premiums, will increasing their power to influence directors and managers promote the long-term health of the corporation.

\section{The Five-Year Report}

Institutional stockholders typically lack the resources to investigate and evaluate the performance of each company in their portfolios, limiting their ability to participate effectively in corporate governance. ${ }^{133}$ The five-year report contemplated by the quinquennial proposal would reduce the need for investigation by providing detailed information on the corporation's performance and business plans. The critique of the five-year report by independent advisors would fulfill the evaluation function, minimizing the need for stockholders to expend their own resources in order to judge the validity of the corporation's own report.

131 Gilson and Kraakman, Reinventing the Outside Director at $39-42 \& \mathrm{n} 71$ (cited in note 1). For example, Professor Gilson was co-chairman of the USX Corporation shareholder committee, formed by corporate raider Carl C. Icahn "to press for the rapid sale or spinoff of the USX Corporation's steel business." Gregory A. Robb, Icahn Group to Urge USX Sale of Steel Unit, NY Times D5 (Nov 15, 1990).

132 See text at notes 78-80.

133 See, for example, Jensen, Harv Bus Rev at 66 (cited in note 107) (too costly for institutional investors to become involved in major decisions and long-term strategies of the companies in which they invest); John Plender, The Limits to Institutional Power, Financial Times $\$ 1$ at 20 (May 22, 1990) (institutional stockholders in the United Kingdom lack industry-specific expertise and information needed to play a role in corporate strategy). 
1. The corporation's report.

The quinquennial proposal contemplates that the corporation would continue to issue annual reports as currently required for public corporations. In the quinquennial year, however, the corporation would issue a far more thorough document, resembling the "blue book" evaluation of the corporation typically prepared by a corporation's investment banker or management consultant. First, it would review the corporation's performance for the prior five years against the five-year plan set forth in its prior five-year report, and against the performance of other companies in the corporation's industry, the market in general, and any other relevant indices. A narrative description would evaluate the performance, explain trends, and review the reasons for the corporation's operating successes and failures.

The report would also detail the corporation's five-year business plan, including projections, the assumptions underlying them, the factors likely to affect whether the projections are met, and the corporation's ability to control or influence these factors. These projections should not raise liability concerns in light of the federal safe-harbor rules that protect companies against claims of securities fraud in connection with projections made in good faith. ${ }^{\mathbf{1 3 4}}$ The SEC might also promulgate special safe-harbor provisions for the five-year report.

The report would discuss the return on investment if the corporation's projections were met, and the dividend stream anticipated by the corporation. If the corporation plans to retain earnings instead of paying them out as dividends, the report would discuss the anticipated uses of these funds. The report would also contain a narrative description of the corporation's five-year strategic plan, the steps the corporation intends to take to accomplish its goals, and the anticipated short-term and long-term implications of the plan for the corporation's financial results.

Some may be concerned that the five-year plan would set goals that could prove too easy to meet in the event of an economic upswing that begins after the plan is drafted. ${ }^{135}$ Each five-year report, however, would compare historical performance not only against the corporation's plan, but also against the performance of other companies in the industry, the market in general, and other relevant measures. These requirements, together with the advisor's 
independent report and the likelihood of a continuing dialogue among directors, managers, and stockholders throughout the fiveyear period, would ensure that managers and directors made every effort to exceed their targets if general economic and other conditions permit.

\section{The independent advisor's evaluation.}

The separate advisor's report would address the concern that institutional investors might not be able to judge an acceptable five-year plan. ${ }^{136}$ The advisor selected by the board to report to the stockholders could be an investment banking firm, consulting firm, or similar entity that provides other services to the corporation, or a firm engaged solely for the purpose of rendering the evaluation. The advisor's appointment by a board with a majority of outside directors, its direct relationship and responsibility to stockholders, and the importance of its reputation for integrity would work to assure the independence and quality of the advisor's report. If additional assurance of independence is desired, the advisor could be appointed by a committee, such as the audit committee, consisting entirely of outside directors. Moreover, institutional stockholders would quickly determine which advisors' evaluation reports were worthwhile and would lead corporations to select these advisors. Given these practical safeguards, there is no need to disqualify advisors who have prior working relationships with the corporation. These firms may be the most familiar with the corporation and its operations, and therefore the most logical and capable candidates to perform the evaluation.

While the advisor would be free to include such information in the evaluation as the advisor believed necessary, at a minimum the evaluation would: (1) review the previous five years' performance by the corporation, assessing the successes and failures of the corporation and the comparative performance of other corporations, both in the industry and in general; (2) comment on management's explanation of the corporation's performance; (3) review the projections in the corporation's report, as well as the assumptions underlying the projections and the factors likely to affect the corporation's ability to meet the projections; (4) assess the corporation's ability to meet the projections; (5) evaluate the corporation's strategic plan for the next five years; and (6) comment on the stock- 
holder invéstment objectives likely to be met by successful implementation of the plan.

The advisor would have the benefit of the same safe harbor as the corporation, and would be permitted a customary indemnification from the corporation, which would exclude acts of negligence. As in the case of independent accountants evaluating a firm's financial reports, possible liability for negligence, ${ }^{137}$ and, more importantly, the concern for reputation, would motivate care by the advisor.

3. Benefits of the report and evaluation.

The report and evaluation would encourage stockholders to view their shares as a stake in the operating performance of the corporation rather than as a mere financial instrument. Along with the long-term orientation imposed by the quinquennial election of directors, the report and evaluation would give institutional stockholders the means to understand the strategic direction and corporate objectives of their portfolio companies, and to intervene or sell their shares if they differ with these plans. ${ }^{138}$

The discipline of the five-year report would also improve the quality of annual reporting. Stockholders would demand annual reports that analyze where the corporation stands within the fiveyear framework, the causes and consequences of any discrepancies between performance and projections, and what changes, if any, are necessary for the business plan. Managers and directors interested in retaining their positions at the quinquennial meeting

${ }^{197}$ See, for example, Schneider v Lazard Freres \& Co., 159 AD2d 291, 552 NYS2d 571 (1990) (investment bankers who advised a Special Committee of the board of directors in a sale-of-control context could be liable in negligence to the company's stockholders). For criticism of the court's holding, see Herbert M. Wachtell, Eric M. Roth, and Andrew C. Houston, Investment Banker Liability to Shareholders in the Sale-of-Control Context, NY L J 1 (Mar 29, 1990); John C. Coffee, Jr., New York's New Doctrine of 'Constructive Privity', NY L J 5 (Jan 25, 1990). See also Rachel Davies, Bidders Can Sue in Takeover Case, Financial Times 33 (Oct 30, 1990) (reporting on 1990 English Court of Appeal decision holding that the financial advisors and auditors of a company may be liable to an unwanted takeover bidder for allegedly negligently prepared financial statements and forecasts issued before and during the pendency of the bid, on which the bidder could foreseeably rely in deciding whether to make or increase its offer).

${ }^{138}$ For excellent suggestions on how to reform corporate reporting, see generally Peter N. McMonnies, ed, Making Corporate Reports Valuable (Kogan Page, 1988) (urging reports that encourage a long-term perspective). The study, prepared by the Institute of Chartered Accountants of Scotland, notes the need for an increased level of independent assessment of corporate reports. The study suggests, as is contemplated by the quinquennial proposal, that the assessor's role be expanded far beyond the role of the typical outside accountant in the current corporate reporting scheme. Id at 84 . 
would naturally provide this sort of useful information in the interim years.

The expanded information contained in the five-year report and evaluation, and the improved quality of annual reporting, would enable analysts to better assess the performance and prospects of each corporation, and would increase investor confidence in the expected performance of an investment. Perceived investment risk to stockholders should decline in turn, resulting in a lower risk premium and a lower cost of capital to the corporation. The additional information would also assist stockholders in more closely matching their investment objectives to the objectives of the corporations in which they invest, thereby further reducing the risk premium and the cost of equity capital. Ultimately, the quinquennial proposal would bring institutional investor knowledge in the United States and the United Kingdom closer to the level now seen in Japan and Germany. This could bring the return on equity demanded by investors in our markets, and the cost of capital, more in line with that of the Japanese and German markets. ${ }^{139}$

Some corporations may argue that the requirements of the five-year report are too onerous, or that wide distribution of projections or the advisor's evaluation would damage the corporation. Well-managed corporations, however, should welcome the five-year reports and the quinquennial proposal as a whole. Most well-managed corporations today develop, at least internally, detailed strategic plans and five-year projections. Any corporation seeking financing must go through such a process; a well-managed corporation and its management should want to develop a detailed long-term strategic plan and measure its performance against this plan.

Nor can the argument that publication of projections and strategic plans would harm the corporation withstand analysis. On the basis of information already available to them, most good analysts can develop projections for the corporations they follow. These projections do not produce the same investor confidence as management's own projections, but they typically come very close to what the corporation itself would prepare. The quinquennial proposal does not require disclosure of trade secrets or competitively

139 See, for example, Short-termism, part 20, The Economist 76 (June 30, 1990) (cost of capital is higher in United States and United Kingdom than in Japan and Germany); Gary Hector, Why U.S. Banks Are In Retreat, Fortune 95 (May 7, 1990) (from 1983 to 1988 the cost of capital for United States companies was twice that of competitors in Japan and West Germany). 
vital business information. Sophisticated investors understand, and the five-year report would emphasize, that projections constitute a framework, not a crystal ball. Even with such a qualification, however, the framework set forth in the projections and the strategic plan would be of great value in assessing the performance and direction of the corporation.

The real objection of some corporations is likely to be their reluctance to establish a concrete framework against which to judge management's performance or to have management publicly critiqued by an outside advisor. Yet an effective system of corporate governance depends on the ability to evaluate the business performance and direction of the corporation and its management. The corporation least willing to expose itself to such an evaluation probably needs it most.

\section{E. Management Compensation}

1. Compensation linked to performance.

The revision of compensation structures would reinforce the long-term time horizon contemplated by the quinquennial system by directly aligning the managers' personal financial interests with the long-term success of the corporation. Financial incentives and risks for managers in leveraged buyouts contribute significantly to the performance of those buyouts that succeed. ${ }^{140}$ And the dissatisfaction of many managers who want a more significant share of any increase in value generated by the business success of the corporation fuels strong management interest in participating in these buyouts. ${ }^{141}$

Today, managerial compensation is not adequately related to the long-term results of the corporation's business operations. Observers note the "dearth of financial incentives for top management to make the costly and risky decisions that can promise substantial long-term payoffs for the shareholders." ${ }^{142}$ They also complain that high levels of managerial compensation persist in

${ }^{140}$ George Anders, Leaner and Meaner Leveraged Buy-Outs Make Some Companies Tougher Competitors, Wall St J A1 (Sept 15, 1988) (financial risks at stake in LBO force management to be more aggressive). See also Jensen, Harv Bus Rev at 69 (cited in note 107).

${ }^{142}$ Capitalism at 12 (cited in note 10); Sykes, Corporate Takeavers at 11-12 (cited in note 85).

${ }^{142}$ Graef S. Crystal, Cracking the Tax Whip on C.E.O.'s, NY Times Mag 48 (Supplement on the Business World, Sept 23, 1990); see also Sykes, Corporate Takeovers at 11-12 (cited in note 85); Jensen and Murphy, Harv Bus Rev at 39 (cited in note 21). 
corporations whose performance is poor, effectively rewarding managers for corporate failure. ${ }^{143}$ To the extent a large portion of an executive's compensation is set regardless of the corporation's success, the executive lacks any financial motive to improve the business performance of the corporation. Incentive compensation plans tied to the corporation's annual performance, or performance over even shorter time periods, reinforce the problems of shorttermism. ${ }^{144}$

The quinquennial proposal would link significant financial risks and rewards for managers to corporate performance against the corporation's five-year goals. Managers would receive no bonuses or stock awards based on any. shorter time period. ${ }^{145}$ The specific compensation plan for each corporation would be part of the quinquennial plan submitted to stockholders. It could also be subject to evaluation by a compensation consultant, in a manner similar to the advisor's evaluation of the five-year business plan.

\section{An illustrative plan for compensation.}

One possible plan would allocate ten percent of the corporation's shares to management, contingent on at least a twelve-percent increase in the market price of the corporation's shares, compounded over the five-year period (a net increase of 76 percent). The actual increase in market price in any given year would be irrelevant; the plan would look only to the five-year average. Managers would receive half the ten-percent stake if the price increase met the twelve-percent target, and an additional one percent of the corporation's shares for each additional one percent per year market price increase above twelve percent, up to the maximum ten percent if the compound growth rate for the five years reached or exceeded 17 percent. The shares would then vest in equal installments over the next five years, thus limiting the possibility of man-

14s Crystal, NY Times Mag at 48, 54 (cited in note 142); Jensen and Murphy, Harv Bus Rev at 39 (cited in note 21); White, Financial Times at 11 (cited in note 43).

144 Dertouzos, Lester, and Solow, Made in America at 62 (cited in note 46) ("A chief executive whose compensation is a strong function of his company's financial performance in the current year is naturally going to stress short-term results. Indeed, some executivecompensation schemes may encourage managers to adopt an even shorter time horizon than the capital markets do.").

${ }^{145}$ A number of writers have similarly suggested the need to enhance the financial rewards to managers of corporations achieving successful long-term business results while creating a meaningful financial penalty if the corporation's long-term business performance is poor. See sources cited in note 142. See also Porter, The Competitive Advantage of Nations at 529 (cited in note 75 ). 
agement "loading" the first five-year period at the expense of the future. If the corporation did not meet the targeted compound increase in stock price, but otherwise achieved its five-year goals, managers could receive a specified cash bonus. If the corporation fell short of its five-year goals, managers would receive no incentive compensation and no increase in base salary. This compensation plan would encourage successful managers to stay with the corporation, much as the incentive arrangements with managers of leveraged buyout corporations require them to stay on for a minimum period of time. While the time frame for realizing the financial reward would be relatively long, the size of the potential reward would be sufficiently great to lead managers to accept the plan. ${ }^{146}$

The quinquennial proposal would also prohibit employment arrangements that inhibit the ability to replace managers in conjunction with the quinquennial meeting, or that create personal incentives in conflict with the focus on the successful long-term business operations of the corporation. Thus, for example, the corporation could not enter into employment contracts with its managers that extend beyond the quinquennial term. Nor could it offer golden parachutes. ${ }^{147}$ However, broad-based severance policies that provide for severance payments regardless of whether there has been a change of control would be permitted.

Management compensation and employment arrangements would thus complement the quinquennial system's reorientation of the corporation's constituencies around the corporation's long-term business success. This system would remove the structural impediments to the ability of managers to manage for the long term, while the financial reward structure would create positive incentives to adopt a long-term personal time horizon.

F. The Prohibition on Takeovers and Elimination of Takeover Defenses

The quinquennial election would be the sole means of accomplishing nonconsensual changes of control. Between meetings, di-

\footnotetext{
${ }^{148}$ See CEO Roundtable on Corporate Structure and Management Incentives, 3 Continental Bank J Applied Corp Fin 6, 20 (Apr 1990) (Richard Sim, chief executive officer of a company that grants stock options that cannot be exercised for five years, commented, "Unless they're in it for the long haul, they will get discouraged and quit; and that's, quite frankly, just the way I want it.").

147 "Golden parachute" as used here refers to severance contracts providing for large payments to executives who are fired or leave under other specified circumstances following a change of control or sale of the corporation.
} 
rectors would not be removable except for criminal conduct or willful misfeasance. In addition, no stockholder could acquire more than ten percent of a corporation's stock without the board's consent. The would-be acquiror therefore could not purchase a controlling stake in a corporation and then coerce a "consensual" change of control, making the next quinquennial election a fait accompli.

Correspondingly, the quinquennial system would prohibit takeover defense devices and repeal takeover-related state legislation. It would thus eliminate share purchase rights plans, ${ }^{148}$ staggered boards, ${ }^{149}$ supermajority "fair price" provisions, ${ }^{150}$ standstill provisions, ${ }^{151}$ control share acquisition statutes, ${ }^{152}$ and business combination moratorium statutes. ${ }^{153}$ It would reinstate the substance of SEC Rule 19c-4, limiting the ability of public corporations to issue equity with disproportionate voting rights. ${ }^{164}$

${ }^{148}$ Such plans deter control acquisitions not approved by the corporation's board of directors by making inexpensive new shares available to current shareholders other than the acquiror, diluting the acquiror's stake and increasing the leverage of the board in responding to an unsolicited acquisition attempt. Share purchase rights plans were first developed by one of the authors as a response to abusive takeover tactics. In the context of the quinquennial system's restrictions on changes in control, the protections afforded by rights plans would be unnecessary.

140 In these arrangements, one-third of the board typically comes up for reelection each year. Under Delaware law, members of a staggered board may only be removed for cause, unless the charter provides otherwise. 8 Del Code Ann $\S \S 141(d),(k)(1990)$.

${ }^{180}$ These provisions, found in many corporate charters and some state statutes, impose a supermajority voting requirement on mergers, sales of assets, liquidations, and recapitalizations between the corporation and an "interested person" (typically defined as a 10-20 percent stockholder) unless the transaction meets specified price requirements. See, for example, Ill Ann Stat ch 32, § 7.85 (Smith-Hurd 1990).

${ }^{181}$ Under these provisions a stockholder agrees to vote with management at election meetings, or agrees not to contest management's proposals or nominees, in exchange for some corporate concession or as a condition to the corporation's sale of newly issued securities to the stockholder.

152 Control share acquisition statutes provide that shares acquired in a "control share acquisition," defined as the direct or indirect acquisition of shares constituting voting power in the target corporation of at least 20 percent, $331 / 3$ percent, or 50 percent, automatically lose their voting rights unless a majority of the disinterested holders of each class of stock approves. See, for example, Ind Code Ann $\$ \S 23-1-42-1$ to 21-1-42-11 (West 1989); CTS Corp. v Dynamics Corp. of America, 481 US 69 (1987) (upholding constitutionality of Indiana statute).

1ss New York's statute prohibits certain in-state corporations from entering into a business combination, including certain self-dealing transactions as well as mergers and consolidations, with a 20 percent stockholder for five years after the 20 percent threshold is crossed, unless the board grants approval in advance of the 20 percent acquisition. NY Bus Corp Law $\$ 912$ (Law Co-op Supp 1989). See also Amanda Acquisition Corp. v Universal Foods Corp., 877 F2d 496 (7th Cir 1989) (Easterbrook) (upholding constitutionality of similar Wisconsin statute).

16t See note 119. 
The quinquennial proposal would also repeal all constituency statutes. Because hostile takeovers could only occur as a result of stockholder balloting at the quinquennial meeting and, absent bad faith, self-dealing, or fraud, the board's decision to accept or reject a takeover proposal in the interim would not be subject to review, the board would not have to face the issue of whether it could legally consider the interests of non-stockholder constituencies in responding to a takeover attempt. Board, management, and stockholders would focus not on the threat of takeovers, but rather on the long-term business success of the corporation, an-orientation that itself protects the interests of non-stockholder constituencies. ${ }^{155}$

The elimination of hostile takeovers and takeover defenses would channel all nonconsensual changes of control into the quinquennial meeting. This would allow stockholders to focus more clearly on the rationale for any proposed change of control, its likely consequences and its desirability. Stockholders could make a considered decision free of coercion from the acquiror or interference from the incumbent board or management, making it less likely that institutional investors would replace good managers simply to get a takeover premium. The quinquennial meeting would become an effective referendum on the business and investment sense of the proposed change of control. To the extent more than one bidder emerged at the quinquennial meeting, the corporation could establish auction procedures, and the courts could develop rules on permissible postponements of the meeting in response to material developments. ${ }^{156}$

The elimination of takeover battles between quinquennial meetings would also dramatically reduce the amount of management time and and other corporate resources now spent on preventing takeovers and developing takeover-related protections. The quinquennial system would insulate directors and managers for substantial enough periods to permit them to develop their future plans, while at the same time creating a periodic forum in which the directors would be totally uninsulated and subject to recall by the stockholders. While it is possible that the quinquennial meeting could become a focal point for hostile takeover activity, the closer relationship between managers and institutional stock-

180 See Part II.D.

${ }^{166}$ See MAI Basic Four, Inc. v Prime Computer Inc., CA No 10868 (Del Chanc, June 13, 1989) (permitting board to postpone contested election meeting in light of material changes in challengers' takeover bid shortly before scheduled date of meeting). 
holders that the quinquennial system fosters would reduce the likelihood of frequent takeover battles. At worst, the quinquennial system would still free the corporation for substantial periods from preoccupation with the threat of a takeover.

The quinquennial proposal would not permit incumbent directors or management to spend corporate funds in litigation or similar challenges to an opposing slate of directors. The SEC through the federal proxy rules, not incumbent management through private litigation, would police false or misleading statements in the opposing sides' proxy materials. The SEC has policed proxy fights quite diligently. ${ }^{167}$ Whatever additional enforcement benefit private litigation might add, the principle of neutrality toward quinquennial changes in control that underlies the quinquennial system could not permit one side of the proxy contest to use corporate funds to litigate against the other in a litigation initiated by the incumbents. Incumbents could, however, use corporate funds to defend litigation initiated by the opposition.

Eliminating the takeover battleground should remove much of the current friction between managers and institutional stockholders, which is often centered around takeover battles and antitakeover defenses. Institutional stockholders have mounted anti-poison pill stockholder resolution campaigns. Incumbent boards have adopted a panoply of takeover defenses. Legislatures have enacted antitakeover legislation. Stockholders complain that directors are simply trying to entrench themselves. Managers complain that stockholders only care about takeover premiums. The whole debate engenders a degree of distrust and hostility that undermines the necessary spirit of patience and partnership essential for longterm operating success in today's business world.

Under the quinquennial system, institutional stockholders would have to take at least a five-year perspective, or dispose of their investment. Incumbent directors would have to justify the five-year performance and plans of the corporation or risk being voted out of office at the quinquennial meeting. The frequency of the incumbent directors' vulnerability would diminish, but the vulnerability, when it arises, would be heightened due to the existence of easily measured goals and the elimination of takeover defenses. The net result would be that the focus of directors, managers and

\footnotetext{
${ }_{182}$ See David A. Sirignano, Review of Proxy Contests by the Staff of the Securities and Exchange Commission, in Proxy Contests, Institutional Investor Initiatives, and Management Responses 261, 263 (PLI, 1990) (SEC staff acts to "assure that the security holders receive the information they are entitled to under the proxy rules and are not misled.").
} 
stockholders would merge on the corporation's long-term business success.

Mergers, acquisitions, and other business combinations would remain possible during the interim between quinquennial meetings. The incumbent board would retain its duty to examine and evaluate any bona fide acquisition or merger proposal in the context of the corporation's strategic plan. If the directors were to approve an acquisition involving the issuance of securities with more than 25 percent of the corporation's voting power, they would submit the transaction to the corporation's stockholders. ${ }^{168}$ If the directors were to reject a merger or acquisition, however, the stockholders' only recourse would be to replace them at the next quinquennial meeting. Because of the unfettered ability of stockholders to approve a change in control at the quinquennial meeting, directors would not be liable for rejecting an acquisition proposal in the interim, except in cases of bad faith, fraud or selfdealing.

The quinquennial system would remove a significant barrier to negotiated transactions, particularly stock-for-stock transactions that make strategic sense and that avoid the dangerous levels of debt that takeover activity has engendered. Directors are currently reluctant to pursue equity mergers for fear they will put the company "in play" and result in the corporation being forced to accept an undesirable business combination. ${ }^{169}$ By barring nonconsensual takeovers except at the quinquennial meeting, the new system should eliminate such fears. Moreover, the focus on strategic direction that the quinquennial system promotes will likely encourage corporations to give careful consideration to the role strategic acquisitions, mergers, or combinations might play in the develop-

${ }^{188}$ For examples of similar trigger mechanisms, see ALI, Principles of Corporate Governance $\$ 1.32$ at 46-47, 101 (cited in note 27); New York Stock Exchange, Listed Company Manual § 312.03(c) (July 1989); American Stock Exchange, Company Guide § 712 (May 1990); NASDAQ, Notice to Issuers (Oct 16, 1990) (announcing amendment to Schedule D, Part III, Section 5(i) of the By-Laws of the National Association of Securities Dealers, Inc., calling for stockholder approval of any issuance of stock in connection with a merger" or acquisition equal to 20 percent or more of outstanding voting shares).

159 See Paramount Communications, Inc. v Time Inc., 571 A2d 1140 (Del 1989). Although the court held that the preplanned equity merger between Time and Warner could proceed, Time was forced to defend itself at great expense against the hostile advances of Paramount. See generally Laura Landro, David B. Hilder, and Randall Smith, Time Inc.'s Stock Soars $\$ 44$ a Share as Wall Street Bets Paramount's Offer Will Derail Merger With Warner, Wall St J A3, 12 (June 8, 1989) (Paramount's chief executive officer "told analysts that Time 'put itself up for sale' by handing over $60 \%$ ownership to Warner shareholders in the proposed Time-Warner merger."). The authors' law firm represented Warner in this transaction. 
ment of the corporation's business. The quinquennial system might have a slight chilling effect on riskier acquisitions that, if unsuccessful, would threaten the corporation's ability to meet its five-year goals. On the whole, this chill is as likely to be a positive as a negative consequence.

\section{G. The Role of Outside Directors}

1. Incentives for effective monitoring.

The quinquennial proposal would require that a majority of each public corporation's board be composed of directors otherwise unaffiliated with the corporation. Thus, the quinquennial system, like the current system of corporate governance, looks to the outside director as the primary monitor of the business performance of corporate managers. But the quinquennial proposal would make the outside director more vulnerable to replacement by stockholders. Incumbent directors now rarely lose their seats in a proxy fight, except in the context of a tender offer or acquisition proposal. Critics therefore charge that outside directors are not responsive to stockholders because they owe their jobs to management. ${ }^{160}$ With the greatly enhanced ability of stockholders to challenge incumbent directors at the quinquennial meeting, directors who are unresponsive to stockholders would likely lose their seats. Outside directors would have an increased incentive to perform an effective monitoring role.

These directors' ability to monitor would also increase. Some have pointed to the lack of business information given to outside directors, and the lack of time and expertise to evaluate this information, as major obstacles to the performance of outside directors as effective business monitors. ${ }^{161}$ The five-year report and evaluation contemplated by the quinquennial proposal, the expanded annual reporting and internal reviews it is likely to engender, and the continuity of a five-year term, would help to remove these barriers. The framework established by the five-year report should also give further impetus to the growing practice of regular, detailed internal and outside advisor reviews, with the entire board, of the corporation's performance, projections, and strategic plan. Directors

\footnotetext{
${ }^{100}$ See Gilson and Kraakman, Reinventing the Outside Director at 21 (cited in note 1). See also Victor Brudney, The Independent Director-Heavenly City or Potemkin Village?, 95 Harv L Rev 597, 610 \& n 39 (1982) (independent directors are rarely appointed without prior approval of management).

${ }^{101}$ Lorsch, Pawns or Potentates at 84-88 (cited in note 19). See also Coffee, 84 Colum L Rev at 1202-03 (cited in note 46 ).
} 
would insist on the sort of interim reporting and analysis that will help them push the corporation toward its five-year goals, and justify any deviation.

Experience in the last few years shows that directors are very responsive to a proxy fight or even the threat of a proxy fight. Several recent proxy fights/consent solicitations have led to concessions by, or the ultimate sale of, the target corporation. For example, BTR plc's combined proxy contest and tender offer for Norton Company resulted in the sale of Norton to a third-party bidder; Georgia-Pacific Corporation's proxy contest and tender offer for Great Northern Nekoosa Corporation resulted in the sale of Great Northern to Georgia-Pacific; Gemini Partners' proxy contest and consent solicitation to take over the board of directors of Healthco International, Inc. resulted in the appointment of three Gemini nominees to the Healthco board and the pending sale of Healthco to a third party; and the threat by Chartwell Associates to commence a proxy fight with Avon Products to nominate four new directors who would seek to sell the company resulted in Avon giving the dissidents two seats on the board and a stronger voice in running the company. ${ }^{162}$ The quinquennial meeting, and the knowledge that institutional stockholders would have access to the corporate proxy machinery to challenge directors with whom they are dissatisfied, would strengthen the unity, and thus the power, of the outside directors in taking an active role in monitoring the corporation's business performance. In this manner, the remaining barriers to effective monitoring by outside directors would be lowered.

Given the outside directors' heightened monitoring role, the quinquennial proposal would limit the number of boards on which an outside director could serve to three, and would increase their compensation. In addition to an increase in base compensation, the outside director-like managers-would participate substantially in stock-based incentive compensation tied to the corporation's five-year performance. Such provisions would further motivate the corporation's outside directors to fulfill their role as monitors of the corporation's long-term direction and business performance,

162 Randall Smith, Storming the Barricades With a Proxy, Wall St J C1 (May 10, 1990); Healthco to Give Gemini Partners L.P. 3 Seats on New Board, Wall St J C8 (Sept 21, 1990). See also Phillip A. Geiston, New Developments in Proxy Contests, in Tenth Añnual Institute: Proxy Statements, Annual Meetings and Disclosure Documents 651 (Prentice-Hall, 1988) (citing examples of proxy contests to promote a policy of selling or restructuring the company). The authors' law firm represented Norton in its proxy contest with BTR, and Healthco in its proxy contest with Gemini. 
and would meet the complaint of some institutional investors as to the minimal share ownership of most outside directors.

2. The perils of special-interest directors.

Professors Gilson and Kraakman argue that traditional outside directors cannot be effective monitors of managerial performance because, through the nomination process and through social ties, they are tied too closely to the management they monitor, and because they are too independent of stockholders. ${ }^{163}$ The first part of this argument reflects a view that managers and directors must have an adversarial relationship in order for the monitoring function to be successful. In fact, the opposite is true. The director-manager relationship must be a cooperative one, not an adversarial one, in order to be effective. While the adversarial director or board may have the ultimate threat of firing to enforce their policies, the likelihood of full and successful responsiveness by managers to the views of directors is much greater when the manager is motivated by respect and friendship than when motivated by fear. ${ }^{164}$

The second part of the argument reflects the view that an outside director cannot be responsive to a corporate constituency without being nominated by, or specially designated to represent, that constituency. The quinquennial proposal responds to this concern by aligning the interests of the various corporate constituencies-stockholders, managers, employees, and the corporation itself-around the corporation's long-term business success.

It is not necessary, and indeed it would be divisive, to elect separate classes or groups of directors to represent the various corporate constituencies, or to have any constituency have a separate special right to nominate or advise on the nomination of directors. ${ }^{165} \mathrm{~A}$ board monitors best when it works as a cohesive whole, each director viewing himself as representing all constituencies. ${ }^{168}$ Once the corporation's various constituencies all center on the long-term health of the enterprise as their common goal, then traditional outside directors would have ample incentives to work cooperatively with inside directors, management, stockholders, and

${ }^{18 s}$ See Gilson and Kraakman, Reinventing the Outside Director at 21 (cited in note 1).

184 See note 45 and accompanying text.

${ }^{108}$ Compare Gilson and Kraakman, Reinventing the Outside Director (cited in note 1) (recommending election of professional outside directors by, and beholden to, institutional stockholders).

${ }^{100}$ Lorsch, Pawns or Potentates at 41-54 (cited in note 19) (the more directors explicitly agree about in whose interests they are governing, the more they will feel empowered as a group). 
the other constituencies to improve the corporation's operating performance. For similar reasons, it is not necessary that the chairman of the board be someone other than the chief executive officer. ${ }^{167}$

\section{H. Implementation}

The best way to implement the quinquennial system would be through a comprehensive legislative package, adopted in the United States by Congress and the state legislatures and abroad by Parliament in the United Kingdom, or by a Directive of the European Economic Community to all its member states, including the United Kingdom. ${ }^{168}$ This comprehensive approach would require the corporate world and the institutional investor world in each country to work together toward adoption of the new system. In this Section, we discuss the roles that various groups in the United States could play to make the quinquennial proposal a reality. We then briefly discuss the implementation of the quinquennial proposal in the United Kingdom.

\section{Congress.}

The best hope for coordinated nationwide implementation lies with federal legislation. This legislation could take one of three forms: a) a substantive federal corporation law that would essentially replace existing state law; b) legislation that mandates the quinquennial concept but leaves specific implementation to the states; or c) legislation that complements, but does not mandate, implementation at the state level.

We favor the second approach. While a federal law of corporations is within the power of Congress, ${ }^{169}$ such radical change is unnecessary. There is no need to transfer the responsibility for, and the burden of, corporation law as a whole to the federal government and judiciary. On the other hand, non-mandatory legislation would encourage but not ensure uniform adoption of the quin-

${ }^{107}$ But see id at 184-85 \& n 5 (proposing separation of the offices of chairman of the board and chief executive officer).

108 EEC legislation may take several forms, including Regulations and Directives. Regulations are immediately binding and directly applicable to all member states. Directives bind member states to achieve certain specific results. The results can be achieved in many ways, usually by enacting the appropriate legislation in that member state.

${ }_{168}$ See, for example, Donald E. Schwartz, A Case for Federal Chartering of Corporations, 31 Bus Law 1125, 1146 (1976) (substantial federal interest in operation of large corporations would overcome any Tenth Amendment objection to federal chartering of corporations). 
quennial proposal. While adoption on a state-by-state basis would have some beneficial effect, the quinquennial system would work best as a national solution.

Federal legislation mandating the quinquennial system, but leaving implementation to the states, would ensure nationwide adoption of the quinquennial system, while preserving state control and administration of corporation laws. This legislation would require that within a specified period of time (perhaps two years), each state amend its corporation law to provide for the quinquennial election of directors; the prohibition of nonconsensual changes in control between election meetings; the abolition of takeover defenses and repeal of state antitakeover legislation; access to the corporate proxy machinery for major stockholders; publication of the quinquennial report and evaluation; and guidelines for permissible corporate compensation schemes. We also suggest interim legislation providing for a temporary moratorium on takeovers between the introduction and adoption of quinquennial legislation. This moratorium addresses the concern that the pendency of the quinquennial legislation might prompt a destructive surge in hostile takeover activity. ${ }^{170}$

Federal legislation would implement directly, or delegate to the SEC, necessary revisions to federal proxy and general disclosure laws and rules, the reinstatement of SEC Rule 19c-4, and the repeal of SEC Rule 14a-8. States would maintain whatever other provisions of corporation law they desired, as long as those provisions did not threaten to undercut the quinquennial system. States would also remain responsible for administering their own corporation laws, and state courts would continue to interpret and enforce those laws.

Historically, it has been difficult to achieve the necessary consensus for federal legislation affecting takeovers. ${ }^{171}$ As a first step toward overcoming this difficulty, Congress could create an advisory panel including representatives of both the corporate and the institutional investor worlds. Congress could require the panel to report back shortly with a fully developed legislative proposal supported by both groups. Alternatively, the Treasury Department's task force on corporate governance could undertake to achieve the necessary consensus.

\footnotetext{
170 See Sykes, Corporate Takeovers at 44 (cited in note 85).

${ }^{171}$ See, for example, Thomas G. Donlan, Twice Shy: Congress Unlikely to Try Another Anti-Buyout Bill, Barron's 15 (May 1989).
} 


\section{States.}

If federal legislation initially proves impossible, the next-best alternative would be implementation by individual states. While federal law historically has governed disclosure requirements and proxy procedures, the quinquennial system's proposals in these areas do not conflict with existing federal law and thus could be enacted by the state. The prohibition on nonconsensual changes in control between election meetings is the only element of the quinquennial system that would raise serious constitutional questions if enacted without federal authorization. In light of the obviously legitimate state interest in the quinquennial proposal as a whole, however, enactment of this provision by states should survive any constitutional challenge. ${ }^{172}$ Moreover, even if states could not constitutionally ban nonconsensual changes in control between election meetings, they could accomplish much the same purpose by prohibiting removal of directors between quinquennial meetings or limiting the voting rights attached to shares acquired in excess of a specified percentage of outstanding shares without the approval of the corporation's directors.

State-by-state implementation would begin in states with small populations of major public corporations. A variety of competing constituencies and political forces, similar to those found on the national level, tend to operate in Delaware and other states where large numbers of major corporations are incorporated. If these forces block development of the consensus necessary to achieve federal legislation, they would probably also block passage of legislation in these key states. In a state where a limited number of major corporations are incorporated, however, those corporations and their corporate constituencies could combine to secure enactment of the quinquennial system by the state legislature. Success of the system in a few such states would facilitate its wider adoption.

The first step in this process would be for one or a group of the major corporations in a state to work with the state bar groups to develop a legislative proposal. The corporations would also solicit input and support from any of its major stockholders who desired to participate in the process. Support of a legislative corpo-

172 See CTS Corp. v Dynamics Corp. of America, 481 US 69 (1987) (Indiana's interest in protecting its corporations and regulating their internal affairs outweighed any extraterritorial effects of control share acquisition statute); Amanda Acquisition Corp. $v$ Universal Foods Corp., 877 F2d 496, 503, 506 (7th Cir 1989) (following CTS in upholding constitutionality of Wisconsin's business combination statute). 
rate governance proposal by many of the state's large corporations, their major stockholders, and the state bar groups would virtually guarantee passage.

\section{The Securities and Exchange Commission.}

Development of the federal proxy and disclosure provisions of the quinquennial system would fall naturally within the domain of the SEC. Congress could delegate to the SEC the job of developing detailed rules governing the five-year report and the advisor's evaluation, just as the SEC has historically developed disclosure and reporting rules under existing securities laws. ${ }^{173}$ The SEC would also develop rules governing the access of major stockholders to the corporate proxy machinery just as it currently develops and enforces the federal proxy rules. ${ }^{174}$

The SEC could take the lead in implementation of the quinquennial proposal by developing and advising on federal or state legislative proposals for such implementation. The staff of the SEC has extensive experience with a number of the issues raised by the quinquennial proposal. Representatives of the SEC could serve on the congressional advisory panel charged with developing a federal legislative proposal. Alternatively, the SEC could work with the Treasury task force, or conduct an independent study of the proposal and offer recommendations for improving it.

4. Corporations and institutional investors.

Corporations and institutional investors would serve primarily as advocates for adoption of the quinquennial system. Through public statements, private discussion and legislative lobbying, they could play a key role in developing political support for the proposal. Those who opposed the proposal could engage in similar efforts, encouraging proponents to either accommodate or rebut significant objections.

Business groups such as The Business Roundtable and the National Association of Manufacturers, institutional stockholder groups such as the Council of Institutional Investors, and major public investment funds such as CalPERS, provide preexisting ve-

173 See, for example, 17 CFR $\S \S 240.13 a-1,240.13 a-11$ and 240.13a-13 (1990) (requiring annual, quarterly, and other reports on prescribed forms); 17 CFR $\S 240.13 \mathrm{~d}-1$ (1990) (requiring disclosure of beneficial ownership in excess of five percent of a corporation's shares); 17 CFR $\$ 239.11$ to 239.34 (1990) (setting forth forms prescribing disclosure requirements for registration statements under the Securities Act of 1933).

17417 CFR §§ 240.14a-1 to 240.14a-102 (1990). 
hicles for discussion of the quinquennial proposal. The identification of these groups with fixed positions in the corporate governance debate, however, may create obstacles to constructive dialogue. Accordingly, we also encourage discussion among individual corporate leaders and institutional stockholders. The congressional advisory panel, or any other legislatively appointed panel or commission, would provide an appropriate forum for such discussion.

\section{The United Kingdom:}

Parliament could enact the entire quinquennial system through a comprehensive amendment to the Companies Act, the principal regulatory statute governing public companies in the United Kingdom. ${ }^{175}$ The extensive relationships among industry, merchant banks, institutional stockholders, and governmental agencies such as the Bank of England-for example, in their roles on the City Panel on Takeovers and Mergers ${ }^{176}$-would permit these groups to work together toward implementation of the new system. Alternatively, the United Kingdom's role as a member of the EEC may make it more appropriate to implement the quinquennial system through an EEC Directive to member states. This approach would be analogous to federal legislation in the United States mandating enactment of the quinquennial system but leaving implementation to the states.

As in the United States, the key would be to gain the support of both the corporate world and the institutional investor world. Recognition of the corporate governance problem is high in the United Kingdom, and the perceived need for reform is great. The quinquennial system responds to the concerns voiced in the United Kingdom by participants in the corporate governance debate; accordingly, adoption of the system may be possible.

178 Companies Act 1985, II Palmer's Company Law If A-051 at 1011 (1985). See also Companies Act 1989, II Palmer's Company Law II A-110 at 1509 (1989) (incorporating amendments that reflect, among other things, certain EEC directives).

${ }_{178}$ The Takeover Panel is a non-statutory body that regulates takeovers through its interpretations of the City Code on Takeovers and Mergers, an industry code containing general principles and specific rules relating to takeovers. Members of the Takeover Panel include representatives of merchant banks, investment fund managers and institutional investors, professional accountants, the Bank of England, the Securities Association, the Stock Exchange and the Confederation of British Industry. See generally Tony Shea, Regulation of Takeovers in the United Kingdom, 16 Brooklyn J Intl L 89 (1990); Lord Alexander of Weedon, Q.C., Takeovers: The Regulatory, Scene, 1990 J Bus Law 203. 


\section{Conclusion}

The intensity of the corporate governance debate in the United States and the United Kingdom reflects a deep-seated concern with the present system. Virtually all participants in the debate recognize that the present system will not meet our needs in the 1990s and beyond. We cannot afford to repeat the financial chaos of the 1980s or the crises that inevitably follow such a speculative frenzy. While corporate governance is only one factor in determining the success of our business corporations, it is a key factor. It is imperative that we rebuild the corporate governance system to promote the long-term health of the corporations that form the backbone of our free-market economy.

At the theoretical level, this task entails rejection of the managerial discipline model of corporate governance, which places stockholder wishes, stockholder profit, and the promotion of takeovers on an undeserved pedestal. This model encourages the sort of short-term obsessions that continually undermine the ability of American and British companies to compete in world markets over the long term. In place of the managerial discipline model we propose a theory centered on the corporation's own interest in its long-term business success. This interest, when multiplied many times over, in classical economic theory mirrors the interest of all corporate constituencies and society as a whole.

At the practical level, we urge adoption through the coordinated efforts of many actors-state and federal, public and private- of a quinquennial system of corporate governance. This system would reserve essential decisions of corporate control and strategy for stockholders to decide every five years, in a meeting dedicated to rational and unfettered consideration of the corporation's long-term interests. Not all aspects of the quinquennial system would find favor with corporations or with institutional stockholders; it is not designed to meet the wishes of either. But it would meet the needs of our economies, and lead both corporations and institutions to act in the national interest. 
